\begin{tabular}{c|c|c}
\hline \hline & CLIMATE RESEARCH \\
Vol. 23: 89-110, 2003 & Clim Res & Published January 31 \\
\hline
\end{tabular}

\title{
Proxy climatic and environmental changes of the past 1000 years
}

\author{
Willie Soon $^{1,2, *}$, Sallie Baliunas ${ }^{1,2}$ \\ ${ }^{1}$ Harvard-Smithsonian Center for Astrophysics, 60 Garden Street, MS 16, Cambridge, Massachusetts 02138, USA \\ ${ }^{2}$ Mount Wilson Observatory, Mount Wilson, California 91023, USA
}

\begin{abstract}
The 1000 yr climatic and environmental history of the Earth contained in various proxy records is reviewed. As indicators, the proxies duly represent local climate. Because each is of a different nature, the results from the proxy indicators cannot be combined into a hemispheric or global quantitative composite. However, considered as an ensemble of individual expert opinions, the assemblage of local representations of climate establishes both the Little Ice Age and Medieval Warm Period as climatic anomalies with worldwide imprints, extending earlier results by Bryson et al. (1963), Lamb (1965), and numerous intervening research efforts. Furthermore, the individual proxies can be used to address the question of whether the 20th century is the warmest of the 2nd millennium locally. Across the world, many records reveal that the 20th century is probably not the warmest nor a uniquely extreme climatic period of the last millennium.
\end{abstract}

KEY WORDS: Paleoclimate proxies $\cdot$ Climate change Environmental change $\cdot$ Little Ice Age · Medieval Warm Period

Resale or republication not permitted without written consent of the publisher

\section{INTRODUCTION}

Are the Little Ice Age and Medieval Warm Period widespread climatic anomalies? Lamb (1965) wrote, '[M]ultifarious evidence of a meteorological nature from historical records, as well as archaeological, botanical and glaciological evidence in various parts of the world from the Arctic to New Zealand ... has been found to suggest a warmer epoch lasting several centuries between about A.D. 900 or 1000 and about 1200 or $1300 . .$. Both the "Little Optimum" in the early Middle Ages and the cold epochs [i.e. "Little Ice Age"], now known to have reached its culminating stages between 1550 and 1700, can today be substantiated by enough data to repay meteorological investigation. . . . It is high time therefore to marshal the climatic evidence and attempt a quantitative evidence' (p. 14-15). Research on large-scale patterns of climate change continued with vigor.

Jones et al. (1998) tentatively concluded that while a Little Ice Age cooling existed, little evidence could be found to support or reject a medieval warming. But the updated composite tree-ring summer temperature curve in Fig. 1 of Briffa (2000) shows evidence for an anomalously warm interval from about 950 to 1100 in the northern high-latitude zone, which coincides with Lamb's Medieval Warm Period. Also, a similar early warm period appears prominently in the averaged tree ring chronologies carefully selected and processed from 14 sites spreading over 30 to $70^{\circ} \mathrm{N}$ (Esper et al. 2002).

Those results are but a few of many that have become available since Lamb's analysis. Given advancements in retrieval of information from and extension of surface coverage for the proxies, we review the accumulated evidence on regional climatic anomalies over the last 1000 yr. We also recommend Ogilvie \& Jónsson (2001), who recently provided the most authoritative discussion on the historical development of the longstanding debates on the climatic nature of the Medieval Warm Period and Little Ice Age, especially concerning the North Atlantic, including Iceland. 


\section{WORKING DEFINITIONS}

What are the regional patterns of climatic change over the last $1000 \mathrm{yr}$ ? Accurate results could serve as benchmarks for 20th century global average warming seen in the surface thermometer records and as physical constraints for theories or mechanisms of climate change on timescales of decades to centuries.

The proxies used to study climatic change over the last $1000 \mathrm{yr}$ are addressed individually and therefore locally because they differ in nature too greatly to be quantitatively averaged or compared. To make progress, we consider 3 questions of many individual climate proxies:

(1) Is there an objectively discernible climatic anomaly during the Little Ice Age interval, defined as 1300-1900? This broad period in our definition derives from historical sea-ice, glaciological and geomorphological studies synthesized in Grove $(2001 \mathrm{a}, \mathrm{b})$ and Ogilvie \& Jónsson (2001).

(2) Is there an objectively discernible climatic anomaly during the Medieval Warm Period, defined as 800-1300? This definition is motivated by e.g. Pfister et al. (1998) and Broecker (2001), and is a slight modification of Lamb's original study (1965).

(3) Is there an objectively discernible climatic anomaly within the 20th century that is the most extreme (the warmest, if such information is retrievable) period in the record? An important consideration in answering this question is to distinguish the cases for which the 20th century warming began early in the century versus after the $1970 \mathrm{~s}$, as recorded by surface thermometers. This is necessary if temperature changes are to be related to anthropogenic forcing inputs like increased atmospheric carbon dioxide content.

Anomaly is simply defined as a period of more than $50 \mathrm{yr}$ of sustained warmth, wetness or dryness, within the stipulated interval of the Medieval Warm Period, or a $50 \mathrm{yr}$ or longer period of cold, dryness or wetness within the stipulated Little Ice Age. We define anomaly in the 20th century within each proxy in the same way. The surface instrumental record of the 20th century contains 3 distinct, multidecadal trends: early-century warming, mid-century cooling and late-century warming. But that knowledge comes from instrumental thermometry with its high time resolution and other biases, which preclude a direct comparison to the proxies (which have their own biases). Our goal here is to compare the 20th century objectively with more extended past changes than is available from thermometry. Given the biases of each proxy, Question (3) was answered by asking if, within each proxy record, there was an earlier (pre-20th century) 50 yr interval warmer (or more extreme, in the case of precipitation) than any $50 \mathrm{yr}$ average within the 20th century.
Question (3) differs from Questions (1) and (2). Question (3) looks for a $50 \mathrm{yr}$ anomaly within the 20th century compared to any other anomaly throughout the period of a proxy record. Questions (1) and (2) look for a $50 \mathrm{yr}$ anomaly within the previously suggested 500 and 600 yr intervals of the Medieval Warm Period and Little Ice Age, respectively. Note that in the case of Question (3), we treat the definition of a 50 yr or more period of sustained anomaly in the 20th century no different from that of any prior century. Thus, if a sustained warm anomaly were identified and happened to reside in the Medieval Warm Period and appeared warmer than an anomaly found in the 20th century, then we would assign 'No' to Question (3). Similarly, a proxy record may show both that the 20th century anomaly is the most extreme (warmest) and that the Medieval Warm Period exists. In answering Question (3), the existence of the Medieval Warm Period or Little Ice Age is not considered, because they are assessed independently, in Questions (1) and (2).

We started with the framework of past researchers, namely, the suggested existence of the Medieval Warm Period and Little Ice Age. The goal of the study is to deduce the geographical nature of climatic and environmental conditions during these periods. Distinguishing the 20th century as a separate period is largely a practical bias because of the interest in the role of human activity on Earth's climate and environment.

Another important consideration is that temporary regional cooling (or shift between wet and dry condition) may occur on decadal, but not multidecadal, timescales during the Medieval Warm Period, and similarly, occasional, short-lived regional warming (or shift between wet and dry condition) may occur during the Little Ice Age, as indicated by Grove $(2001 \mathrm{a}, \mathrm{b})$. Thus the terms Medieval Warm Period and Little Ice Age should indicate persistent but not necessarily constant warming or cooling, respectively, over broad areas (see also Stine 1998, Luckman 2000, Grove 2001a,b, Ogilvie \& Jónsson 2001, Esper et al. 2002). Stine (1998) suggests that more appropriate terms may be 'Little Ice-Age Climatic Anomaly' and 'Medieval Climatic Anomaly'. It is also noteworthy that the definitions of discernible, persistent climate anomalies for the Little Ice Age and Medieval Warm Period may include not only distinct changes in the mean but also changes in the multidecadal variance (Ogilvie \& Jónsson 2001). Through the microscope of daily and regional spatial scale variability, it is important to recognize that even the relation between multidecadal mean temperature and its daily variability may undergo significant non-stationary changes (e.g. Knappenberger et al. 2001, who document those time-dependent changes in temperature variability across the United States). 
Also, from a combination of field evidence and modeling based on the understanding from synoptic climatology, Bryson \& Bryson (1997) demonstrated how local and regional factors (for horizontal spatial distances as small as $100 \mathrm{~km}$ ) can produce significantly different precipitation histories for 2 Near East stations (Jerusalem and Kameshli, Syria) and for 2 stations in the Cascade Range of Oregon (mountainous versus coastal-like microclimate sites).

Our classification of a widespread anomaly based on multidecadal persistence at many locales rests on good precedent. For example, the modern globally averaged surface warming inferred from thermometer readings includes large-scale cooling trends over both the Greenland/Labrador Sea area and the eastern region of the United States (30 to $45^{\circ} \mathrm{N} ; 80$ to $110^{\circ} \mathrm{W}$; see Hansen et al. 1999, Robinson et al. 2001) or the Antarctic continent (e.g. Doran et al. 2002) in the last 30 to $50 \mathrm{yr}$. Another example is relative warmth during the Little Ice Age and relative cool during the Medieval Warm Period seen in the borehole record of reconstructed temperature at Taylor Dome, Antarctica $\left(77.8^{\circ} \mathrm{S}, 158.72^{\circ} \mathrm{E}\right.$, elevation $2374 \mathrm{~m})$, compared to results from Greenland's borehole (see Clow \& Waddington 1999), which do not show those features. These variations are of short duration compared to the anomaly, and of limited regional extent

\section{APPROACH}

Table 1 and Figs. 1 to 3 summarize the answers to the questions posed here about local climatic anomalies. For Questions (1) and (2), we answered 'Yes' if the proxy record showed a period longer than $50 \mathrm{yr}$ of cooling, wetness or dryness during the Little Ice Age, and similarly for a period of $50 \mathrm{yr}$ or longer for warming, wetness or dryness during the Medieval Warm Period. A dash indicates that either there is no expert opinion, or that the proxy record does not cover the period in question. A 'Yes?' or 'No?' answer means that the original expert opinion was Yes or No, but that it does not match our criteria; for example, if the interval of warmth during the Medieval Warm Period were too short by our definition to be 'Yes', it would merit 'Yes?'. In several cases in the 20th century, a 'Yes' ${ }^{a}$ designation was assigned for the answer to Question (3) in order to highlight the fact that the 20th century warming first occurred early in the century, ca. 1920-1950, when the air's content of anthropogenic $\mathrm{CO}_{2}$ was still cumulatively small.

A global association for the Little Ice Age or Medieval Warm Period is premature because proxy data are geographically sparse and either or both phe- nomena could be multi-phased events acting under distinct local and regional constraints and modes. Bradley \& Jones (1993) and Hughes \& Diaz (1994) initiated and strongly held the view that the phenomena were not global, but Grove (1996; see especially p. 51 to 54) disagrees. However, in the traditionally datarich areas of Western Europe or the Northern Atlantic including Iceland and Greenland, both the Little Ice Age and Medieval Warm Period do exist as distinct climate anomalies (Pfister et al. 1998, Grove 2001a, Ogilvie \& Jónsson 2001). No objective proof discredits the existence of those phenomena in other regions. Thus, like other researchers (Lamb 1965, Porter 1986, Grove 1996, Kreutz et al. 1997), we start with previously indicated periods of Little Ice Age and Medieval Warm Period, and ask whether they are widespread, teleconnected events that need not necessarily last throughout the defined periods. The terms Medieval Warm Period and Little Ice Age remain practical and viable, especially considering the potential extension of the concept to past and future climatic events that are 'similar or equivalent' in physical scope (e.g. Bond et al. 1997, 1999).

Current knowledge on the diverse range of local climatic behavior suggests that the Medieval Warm Period and the Little Ice Age are not expected to be homogeneous and sustained. To define the beginning and end dates of these climate anomalies requires better understanding (for the Little Ice Age see Porter 1981, 1986, Kaser 1999, Grove 2001a,b, Luckman 2000 Schuster et al. 2000, Winkler 2000, Ogilvie \& Jónsson 2001, Hendy et al. 2002). Imprecise data on the beginning and end of both events contributes in part to confusion about the phenomena. For example, Ogilvie \& Farmer (1997) have commented that Lamb's suggestion of a Medieval Warm Period may not be supported by documentary data even for England because their extensive studies based on a historical dataset showed that England suffered relatively cold winters from 1260 to 1360 . However, as that period is near the transition between the Medieval Warm Period and Little Ice Age defined in this study, this fact does not strongly contradict our results. Evidence based primarily on glacier activity points to both a poorly defined beginning and end of the Medieval Warm Period, while the Little Ice Age interval seems to have had a gradual beginning but more abrupt end. Although the notion of the Medieval Warm Period or Little Ice Age with sharply defined transitions may be a convenient one, it is probably a non-physical construct because of large regional differences in the timing of both phenomena. As suggested by Grove (2001a), an inhomogeneous climate pattern (though not necessarily an analog) can already be identified in the 20th century warm intervals as defined by instrumental records. 
Table 1. A full list of paleoclimatic proxies that have sufficient length of continuous records to entertain the 3 specifc questions: (1) Is there an objectively discernible climatic anomaly during the Little Ice Age interval (A.D. 1300-1900) in this proxy record? (2) Is there an objectively discernible climatic anomaly during the Medieval Warm Period (A.D. 800-1300) in this proxy record? (3) Is there an objectively discernible climatic anomaly within the 20th century that is the most extreme (the warmest, if such information is available) period in the record? A question mark after an answer indicates uncertainty or indecision. Symbols for the type of climate proxy used include B: borehole; Cl: cultural; D: documentary; G: glacier advance or retreat; Gm: geomorphology; In: instrumental, Is: isotopic analysis from lake sedimentary or ice cores, tree or peat celluloses, corals, stalagmite or biological fossils; Ic: net ice accumulation rate, including dust or chemical counts; Lf: lake fossils and sediments; river sediments; Ml: melt layers in ice cores; Mp: multiproxy (any combination of proxies listed here); Pf: phenological and paleontological fossils; Po: pollen; Sd: seafloor sediments; Sp: speleothem isotopic or luminescent analysis; T: tree ring growth, either ring width or maximum latewood density, including shifting tree line positions; Ts: tree stumps in lakes, marshes and streams

\begin{tabular}{|c|c|c|c|c|c|c|c|}
\hline \multirow[t]{2}{*}{ Location } & \multirow[t]{2}{*}{ Latitude } & \multirow[t]{2}{*}{ Longitude } & \multirow[t]{2}{*}{ Type } & \multirow[t]{2}{*}{ Source } & \multicolumn{3}{|c|}{ Answer } \\
\hline & & & & & (1) & $(2)$ & (3) \\
\hline Worldwide & - & - & $\mathrm{Mp}$ & Mann et al. (1999) & Yes & No & Yes $^{\mathrm{a}}$ \\
\hline Arctic wide & - & - & $\mathrm{Mp}$ & Overpeck et al. (1997) & Yes & - & Yes $^{\mathrm{a}}$ \\
\hline Worldwide & - & - & $\mathrm{Mp}$ & Crowley \& Lowery (2000) & Yes & No & Yes $^{\mathrm{a}}$ \\
\hline Worldwide & - & - & $\mathrm{Mp}$ & Jones et al. (1998) & Yes & No & Yes $^{\mathrm{a}}$ \\
\hline Worldwide & - & - & $\mathrm{T}$ & Briffa (2000) & Yes & No & Yes $^{\mathrm{a}}$ \\
\hline Worldwide & - & - & $\mathrm{T}$ & Briffa et al. (2001) & Yes & - & Yes $^{\mathrm{a}}$ \\
\hline Worldwide & - & - & $\mathrm{T}$ & Jones et al. (2001) & Yes & - & Yes $^{\mathrm{a}}$ \\
\hline NH mid-latitude & - & - & $\mathrm{T}$ & Esper et al. (2002) & Yes & Yes & No \\
\hline Worldwide & - & - & $\mathrm{Mp}$ & Lamb $(1977,1982)$ & Yes & Yes & - \\
\hline Worldwide & - & - & $\mathrm{G}+\mathrm{Is}$ & Porter (1986) & Yes & Yes & - \\
\hline Worldwide & - & - & $\mathrm{G}$ & Grove \& Switsur (1994) & - & Yes & - \\
\hline Worldwide & - & - & $\mathrm{T}+\mathrm{G}+\mathrm{D}$ & Hughes \& Diaz (1994) & Yes & No? ${ }^{b}$ & $\mathrm{No} ?^{b}$ \\
\hline Worldwide & - & - & $\mathrm{Mp}$ & Grove (1996) & - & Yes & - \\
\hline Worldwide & - & - & $\mathrm{B}$ & Huang et al. (1997) & Yes & Yes & No \\
\hline Worldwide & - & - & $\mathrm{D}$ & Perry \& Hsu $\left(2000^{\circ}\right)$ & Yes & Yes & No \\
\hline Worldwide & - & - & $\mathrm{D}$ & deMenocal (2001) & Yes & Yes & - \\
\hline Americas & - & - & $\mathrm{Ts}+\mathrm{Gm}+\mathrm{Mp}$ & Stine (1998) & - & Yes & - \\
\hline \multirow[t]{2}{*}{ N. Atlantic (Iceland) } & $63-66^{\circ} \mathrm{N}$ & $14-24^{\circ} \mathrm{W}$ & $\mathrm{Mp}$ & Ogilvie et al. (2000) & & & \\
\hline & & & & Ogilvie \& Jónsson (2001) & Yes & Yes & No \\
\hline N. Atlantic (S. Greenland) & $60-70^{\circ} \mathrm{N}$ & $20-55^{\circ} \mathrm{W}$ & $\mathrm{Mp}$ & Ogilvie et al. (2000) & Yes & Yes & No \\
\hline W. Europe & $45-54^{\circ} \mathrm{N}$ & $0-15^{\circ} \mathrm{E}$ & $\mathrm{Mp}$ & Pfister et al. (1998) & Yes & Yes & No \\
\hline N. Atlantic (Europe) & $35-70^{\circ} \mathrm{N}$ & $25^{\circ} \mathrm{W}-30^{\circ} \mathrm{E}$ & $\mathrm{In}+\mathrm{D}$ & Luterbacher et al. (2000) & Yes & - & - \\
\hline Central England & $52^{\circ} \mathrm{N}$ & $2^{\circ} \mathrm{E}$ & $\mathrm{In}+\mathrm{D}$ & Lamb 65, Manley (1974) & Yes & Yes & No \\
\hline S. Spain & $37.30^{\circ} \mathrm{N}$ & $4.30^{\circ} \mathrm{W}$ & $\mathrm{In}+\mathrm{D}$ & Rodrigo et al. (2000) & Yes & - & No \\
\hline Crete Is. & $35.15^{\circ} \mathrm{N}$ & $25.00^{\circ} \mathrm{E}$ & $\mathrm{D}$ & Grove \& Conterio (1995) & Yes & - & No \\
\hline Mid-Russia & $50-60^{\circ} \mathrm{N}$ & $30-50^{\circ} \mathrm{E}$ & $\mathrm{In}+\mathrm{D}$ & Borisenkov (1995) & Yes & - & - \\
\hline Czech Republic & $48.5-51.2^{\circ} \mathrm{N}$ & $12-19^{\circ} \mathrm{E}$ & $\mathrm{In}+\mathrm{B}$ & Bodri \& Cermák (1999) & Yes & Yes & Yes? \\
\hline S. USA & $37-38^{\circ} \mathrm{N}$ & $107.5-109.5^{\circ} \mathrm{W}$ & $\mathrm{Pf}+\mathrm{Cl}+\mathrm{D}$ & Petersen (1994) & Yes & Yes & - \\
\hline E. China (Guang Dong Prov.) & $22-25^{\circ} \mathrm{N}$ & $112-114.3^{\circ} \mathrm{E}$ & $\mathrm{D}$ & Chan \& Shi (2000) & Yes & - & - \\
\hline E. China-wide & $20-40^{\circ} \mathrm{N}$ & $90-120^{\circ} \mathrm{E}$ & $\mathrm{D}$ & Song $(2000)$ & Yes & - & No? \\
\hline Japan & $30-40^{\circ} \mathrm{N}$ & $125-145^{\circ} \mathrm{E}$ & $\mathrm{D}$ & Tagami $(1993,1996)$ & Yes & Yes & No \\
\hline S. Africa & $22.2^{\circ} \mathrm{S}$ & $28.38^{\circ} \mathrm{E}$ & $\mathrm{Cl}$ & Huffman (1996) & Yes & Yes & - \\
\hline E. Greenland (Nansen Fjord) & $68.3^{\circ} \mathrm{N}$ & $29.7^{\circ} \mathrm{W}$ & Is & Jennings \& Weiner (1996) & Yes & Yes & No \\
\hline C. Greenland (Crête) & $71.12^{\circ} \mathrm{N}$ & $37.32^{\circ} \mathrm{W}$ & Is & Dansgaard et al. (1975) & Yes & Yes & No \\
\hline C. Greenland (GRIP) & $72.6^{\circ} \mathrm{N}$ & $37.6^{\circ} \mathrm{W}$ & $\mathrm{B}$ & Dahl-Jensen et al. (1998) & Yes & Yes & No \\
\hline S. Greenland (Dye 3) & $65.2^{\circ} \mathrm{N}$ & $43.8^{\circ} \mathrm{W}$ & $\mathrm{B}$ & Dahl-Jensen et al. (1998) & Yes & Yes & No \\
\hline C. Greenland (GISP2) & $72.58^{\circ} \mathrm{N}$ & $38.5^{\circ} \mathrm{W}$ & $\mathrm{IC}+\mathrm{Ml}$ & Meese et al. (1994) & Yes & Yes & No \\
\hline C. Greenland (GISP2) & $72.58^{\circ} \mathrm{N}$ & $38.5^{\circ} \mathrm{W}$ & Is & Stuiver et al. (1995) & Yes & Yes & No \\
\hline Svalsbard & $79^{\circ} \mathrm{N}$ & $15^{\circ} \mathrm{E}$ & $\mathrm{Ml}$ & Tarussov (1995) & Yes & Yes & No \\
\hline Devon Island & $75^{\circ} \mathrm{N}$ & $87^{\circ} \mathrm{W}$ & $\mathrm{Ml}$ & Koerner (1977) & Yes & - & Yes $^{\mathrm{a}}$ \\
\hline Ellesmere Island & $80.7^{\circ} \mathrm{N}$ & $73.1^{\circ} \mathrm{W}$ & $\mathrm{Ml}$ & Koerner \& Fisher (1990) & Yes & Yes & No \\
\hline Ellesmere Island & $80.7^{\circ} \mathrm{N}$ & $73.1^{\circ} \mathrm{W}$ & $\mathrm{B}+\mathrm{Is}$ & Beltrami \& Taylor (1995) & Yes & Yes & No \\
\hline Gulf of Alaska & $60-61^{\circ} \mathrm{N}$ & $149^{\circ} \mathrm{W}$ & $\mathrm{G}+\mathrm{T}$ & Calkin et al. (2001) & Yes & Yes & - \\
\hline Swiss Alps (Gorner Glacier) & $45.8-46.5^{\circ} \mathrm{N}$ & $7.75-8.16^{\circ} \mathrm{E}$ & $\mathrm{G}+\mathrm{Gm}$ & Holzhauser (1997) & Yes & Yes & No \\
\hline (Grosser Aletsch Glacier) & $45.8-46.5^{\circ} \mathrm{N}$ & $7.75-8.16^{\circ} \mathrm{E}$ & $\mathrm{Is}+\mathrm{T}$ & Holzhauser (1997) & Yes & Yes & No \\
\hline South Georgia Island & $54-55^{\circ} \mathrm{S}$ & $36-38^{\circ} \mathrm{W}$ & $\mathrm{G}+\mathrm{Gm}$ & Clapperton et al. (1989) & Yes & Yes & - \\
\hline Southern Alps (Mueller Glacier) & $43.44^{\circ} \mathrm{S}$ & $170.06^{\circ} \mathrm{E}$ & $\mathrm{G}+\mathrm{Gm}$ & Winkler (2000) & Yes & - & - \\
\hline Antarctica (James Ross Island) & $64.22^{\circ} \mathrm{S}$ & $57.68^{\circ} \mathrm{W}$ & Is & Aristarain et al. (1990) & Yes? & - & No \\
\hline Antarctica (Law Dome) & $66.73^{\circ} \mathrm{S}$ & $112.83^{\circ} \mathrm{E}$ & Is & Morgan (1985) & Yes & Yes & No \\
\hline Antarctica (Victoria Land) & $74.33^{\circ} \mathrm{S}$ & $165.13^{\circ} \mathrm{E}$ & $\mathrm{G}+\mathrm{Gm}+\mathrm{Is}$ & Baroni \& Orombelli (1994) & Yes & Yes & - \\
\hline
\end{tabular}


Table 1 (continued)

\begin{tabular}{|c|c|c|c|c|c|c|c|}
\hline Location & Latitude & Longitude & Type & Source & (1) & $\begin{array}{c}\text { Answe } \\
(2)\end{array}$ & (3) \\
\hline Antarctica (Dome C) & $74.65^{\circ} \mathrm{S}$ & $124.17^{\circ} \mathrm{E}$ & Is & Benoist et al. (1982) & Yes & Yes & No \\
\hline $\begin{array}{l}\text { Prince William Sound, Alaska } \\
\text { Alberta, Canada }\end{array}$ & $60^{\circ} \mathrm{N}$ & $149^{\circ} \mathrm{W}$ & $T+G$ & Barclay et al. (1999) & \multicolumn{2}{|c|}{ Alberta, Canada } & - \\
\hline Columbia Icefield & $52.2^{\circ} \mathrm{N}$ & $117.8^{\circ} \mathrm{W}$ & $\mathrm{T}+\mathrm{In}+\mathrm{G}$ & Luckman et al. (1997) & Yes & Yes & Yes $^{\mathrm{a}}$ \\
\hline N. Québec & $57.73^{\circ} \mathrm{N}$ & $76.17^{\circ} \mathrm{W}$ & $\mathrm{T}$ & Arseneault \& Payette (1997) & - & Yes & - \\
\hline Central US & $33-49^{\circ} \mathrm{N}$ & $91-109^{\circ} \mathrm{W}$ & $\mathrm{T}+\mathrm{Mp}$ & $\begin{array}{l}\text { Woodhouse \& } \\
\text { Overpeck (1998) }\end{array}$ & Yes & Yes & Yes $^{a}$ \\
\hline E. Idaho & $44.1^{\circ} \mathrm{N}$ & $114^{\circ} \mathrm{W}$ & $\mathrm{T}$ & Biondi et al. (1999) & Yes & - & No \\
\hline N. Carolina & $34.5^{\circ} \mathrm{N}$ & $78.3^{\circ} \mathrm{W}$ & $\mathrm{T}$ & Stahle et al. (1988) & Yes & Yes & No? \\
\hline California (SN) & $36.5-37.5^{\circ} \mathrm{N}$ & $118.5-120.5^{\circ} \mathrm{W}$ & $\mathrm{T}$ & Graumlich (1993) & Yes & Yes & No \\
\hline California (SN) & $36.5-37.5^{\circ} \mathrm{N}$ & $118.5-120.5^{\circ} \mathrm{W}$ & $\mathrm{T}$ & Scuderi (1993) & Yes & Yes & No \\
\hline California (SN) & $36-38^{\circ} \mathrm{N}$ & $118-120^{\circ} \mathrm{W}$ & $\mathrm{T}$ & Swetnam (1993) & Yes & Yes & No \\
\hline New Mexico & $34.5^{\circ} \mathrm{N}$ & $108^{\circ} \mathrm{W}$ & $\mathrm{T}$ & Grissino-Mayer (1996) & Yes & Yes & No \\
\hline Central Eq. Pacific (NINO 3.4) & $5^{\circ} \mathrm{N}-5^{\circ} \mathrm{S}$ & $160^{\circ} \mathrm{E}-150^{\circ} \mathrm{W}$ & $\mathrm{T}+\mathrm{In}$ & Evans et al. (2000) & Yes & Yes? & No \\
\hline C. Siberia (Taymir + Putoran) & $72.47^{\circ} \mathrm{N}$ & $102^{\circ} \mathrm{E}$ & $\mathrm{T}$ & Naurzbaev \& Vaganov (2000) & Yes & Yes & No \\
\hline Kola Peninsula & $67-68^{\circ} \mathrm{N}$ & $33-34^{\circ} \mathrm{E}$ & $\mathrm{T}+\mathrm{Is}$ & Hiller et al. (2001) & - & Yes & - \\
\hline N. Fennoscandia & $68^{\circ} \mathrm{N}$ & $22^{\circ} \mathrm{E}$ & $\mathrm{T}$ & Briffa et al. (1992) & Yes & Yes & No \\
\hline NE. Italy & $45^{\circ} \mathrm{N}$ & $10^{\circ} \mathrm{E}$ & $\mathrm{T}$ & Serre-Bachet (1994) & Yes & Yes & No? \\
\hline Morocco & $28-36^{\circ} \mathrm{N}$ & $2-12^{\circ} \mathrm{W}$ & $\mathrm{T}$ & Till \& Guiot (1990) & Yes & Yes? & No \\
\hline Mongolia (Tarvagatay Mts.) & $48.3^{\circ} \mathrm{N}$ & $98.93^{\circ} \mathrm{E}$ & $\mathrm{T}$ & Jacoby et al. (1996) & Yes & - & Yes \\
\hline Mongolia (Tarvagatay Mts.) & $48.3^{\circ} \mathrm{N}$ & $98.93^{\circ} \mathrm{E}$ & $\mathrm{T}+\mathrm{D}$ & D'Arrigo et al. (2001) & Yes & Yes & Yes \\
\hline \multicolumn{8}{|l|}{ N. Patagonia (Rio Alerce, } \\
\hline Argentina) & $41.17^{\circ} \mathrm{S}$ & $71.77^{\circ} \mathrm{W}$ & $\mathrm{T}$ & Villalba (1990) & Yes & Yes & No \\
\hline S. Chile (Lenca) & $41.55^{\circ} \mathrm{S}$ & $72.6^{\circ} \mathrm{W}$ & $\mathrm{T}$ & Lara \& Villalba (1993) & Yes & No & No \\
\hline S. South America & $33-55^{\circ} \mathrm{S}$ & $60-75^{\circ} \mathrm{W}$ & $\mathrm{T}+\mathrm{G}$ & Villalba (1994) & Yes & Yes & No \\
\hline W. Tasmania & $42^{\circ} \mathrm{S}$ & $146.5^{\circ} \mathrm{E}$ & $\mathrm{T}$ & Cook et al. (2000) & No & Yes & Yes? \\
\hline New Zealand & $35-48^{\circ} \mathrm{S}$ & $167-177^{\circ} \mathrm{E}$ & $\mathrm{T}$ & D'Arrigo et al. (1998) & Yes & - & No \\
\hline N. Scandinavia & $68^{\circ} \mathrm{N}$ & $20^{\circ} \mathrm{E}$ & $\mathrm{T}+\mathrm{G}$ & Karlén (1998) & Yes & Yes & No \\
\hline California (SN) & $38^{\circ} \mathrm{N}$ & $110^{\circ} \mathrm{W}$ & Ts & Stine (1994) & - & Yes & No \\
\hline California (SN) & $37.5^{\circ} \mathrm{N}$ & $119.45^{\circ} \mathrm{W}$ & Ts & Stine (1994) & - & Yes & No \\
\hline California (SN) & $38.38^{\circ} \mathrm{N}$ & $119.45^{\circ} \mathrm{W}$ & Ts & Stine (1994) & - & Yes & No \\
\hline California (SN) & $38.85^{\circ} \mathrm{N}$ & $120.47^{\circ} \mathrm{W}$ & Ts & Stine (1994) & - & Yes & No \\
\hline Patagonia & $48.95^{\circ} \mathrm{S}$ & $71.43^{\circ} \mathrm{W}$ & Ts & Stine (1994) & - & Yes & - \\
\hline Patagonia & $50.47^{\circ} \mathrm{S}$ & $72.97^{\circ} \mathrm{W}$ & Ts & Stine (1994) & - & Yes & - \\
\hline NW Michigan (L. Marion) & $45^{\circ} \mathrm{N}$ & $85^{\circ} \mathrm{W}$ & Po & Bernabo (1981) & Yes & Yes & Yes? \\
\hline \multicolumn{8}{|l|}{ Qinghai-Tibetan Plat. } \\
\hline (Dunde Ice Cap) & $38.1^{\circ} \mathrm{N}$ & $96.4^{\circ} \mathrm{E}$ & Po & Liu et al. (1998) & Yes & Yes & Yes? ${ }^{\mathrm{a}, \mathrm{d}}$ \\
\hline NE China (Maili) & $42.87^{\circ} \mathrm{N}$ & $122.87^{\circ} \mathrm{E}$ & Po & Ren (1998) & - & Yes & - \\
\hline NE China (Hangzhou) & $30-33^{\circ} \mathrm{N}$ & $105-122^{\circ} \mathrm{E}$ & $\mathrm{Pf}$ & Zhang (1994) & - & Yes & - \\
\hline China (Taibai Mt.) & $33.97^{\circ} \mathrm{N}$ & $107.73^{\circ} \mathrm{E}$ & $\mathrm{Pf}+\mathrm{Po}$ & Tong et al. (1996) & Yes & Yes & No \\
\hline Himalaya & $28.38^{\circ} \mathrm{N}$ & $85.72^{\circ} \mathrm{E}$ & Is & Thompson et al. (2000) & Yes & No & Yes \\
\hline Himalaya (Dasuopu Glacier) & $28.38^{\circ} \mathrm{N}$ & $85.72^{\circ} \mathrm{E}$ & Ic & Thompson et al. (2000) & Yes & - & Yes \\
\hline Guliya Ice Cap & $35.2^{\circ} \mathrm{N}$ & $81.5^{\circ} \mathrm{E}$ & Ic+Is & Thompson et al. (1995) & Yes & Yes & No \\
\hline E. China & $30-40^{\circ} \mathrm{N}$ & $100-120^{\circ} \mathrm{E}$ & $\mathrm{IC}+\mathrm{D}$ & Shi et al. (1999) & Yes & Yes & Yes? \\
\hline W. China (Guliya Cap) & $35.2^{\circ} \mathrm{N}$ & $81.5^{\circ} \mathrm{E}$ & $\mathrm{IC}+\mathrm{D}$ & Shi et al. (1999) & Yes & Yes & Yes? \\
\hline Quelccaya Ice Cap & $13.93^{\circ} \mathrm{S}$ & $70.83^{\circ} \mathrm{W}$ & Is+Ic & Thompson et al. (1986) & Yes & Yes? & No \\
\hline Antarctica (Siple Station) & $75.92^{\circ} \mathrm{S}$ & $84.25^{\circ} \mathrm{W}$ & $\mathrm{Ic}+\mathrm{Is}$ & Mosley-Thompson (1995) & No & - & No \\
\hline Antarctica (Dyer Plateau) & $70.67^{\circ} \mathrm{S}$ & $64.88^{\circ} \mathrm{W}$ & $\mathrm{IC}+\mathrm{Is}$ & Thompson et al. (1994) & Yes? & - & Yes \\
\hline \multicolumn{8}{|l|}{ Antarctica } \\
\hline (Dronning Maud Land) & $76^{\circ} \mathrm{S}$ & $8.05^{\circ} \mathrm{W}$ & Ic+Is & Karlöf et al. (2000) & Yes & Yes? & No? \\
\hline South Pole & $90^{\circ} \mathrm{S}$ & - & Ic & $\begin{array}{l}\text { Mosley-Thompson \& } \\
\text { Thompson (1982) }\end{array}$ & Yes & Yes? & No \\
\hline N. Atlantic & $54.27^{\circ} \mathrm{N}$ & $16.78^{\circ} \mathrm{W}$ & $\mathrm{Sd}$ & Bond et al. (1997) & Yes & Yes & No? \\
\hline N. Atlantic & $44.5^{\circ} \mathrm{N}$ & $46.33^{\circ} \mathrm{W}$ & $\mathrm{Sd}$ & Bond et al. (1999) & Yes & Yes & No \\
\hline N. Atlantic & $56.37^{\circ} \mathrm{N}$ & $27.81^{\circ} \mathrm{W}$ & $\mathrm{Sd}$ & Bianchi \& McCave (1999) & Yes & Yes & No? \\
\hline N. Ellesmere Island & $81^{\circ} \mathrm{N}$ & $80^{\circ} \mathrm{W}$ & $\mathrm{Sd}+\mathrm{Lf}$ & Lamoureux \& Bradley (1996) & ) Yes & Yes & - \\
\hline \multicolumn{8}{|l|}{ SW Baltic Sea } \\
\hline (Bornholm Basin) & $55.38^{\circ} \mathrm{N}$ & $15.4^{\circ} \mathrm{E}$ & $\mathrm{Sd}+\mathrm{Is}$ & Andrén et al. (2000) & Yes & Yes & No \\
\hline \multicolumn{8}{|l|}{ N. Fennoscandia } \\
\hline (L. Tsuolbmajavri) & $68.68^{\circ} \mathrm{N}$ & $22.08^{\circ} \mathrm{E}$ & Lf & Korhola et al. (2000) & Yes & Yes & No \\
\hline
\end{tabular}


Table 1 (continued)

\begin{tabular}{|c|c|c|c|c|c|c|c|}
\hline Location & Latitude & Longitude & Type & Source & (1) & $\begin{array}{l}\text { Answer } \\
(2)\end{array}$ & (3) \\
\hline Switzerland (L. Neuchâtel) & $47^{\circ} \mathrm{N}$ & $6.55^{\circ} \mathrm{W}$ & Lf+Is & Filippi et al. (1999) & Yes & Yes & Yes? \\
\hline NW Scotland (Assynt) & $58.11^{\circ} \mathrm{N}$ & $5.06^{\circ} \mathrm{W}$ & $\mathrm{Sp}$ & Proctor et al. (2000) & Yes & Yes & No \\
\hline W. Ireland & $53.53^{\circ} \mathrm{N}$ & $9.93^{\circ} \mathrm{W}$ & Is & Blackford \& Chambers (1995) & Yes & Yes & - \\
\hline SW Ireland & $52.5^{\circ} \mathrm{N}$ & $9.25^{\circ} \mathrm{W}$ & $\mathrm{Sp}$ & McDermott et al. (2001) & Yes & Yes & - \\
\hline Bermuda Rise & $32.17^{\circ} \mathrm{N}$ & $64.5^{\circ} \mathrm{W}$ & Is & Keigwin (1996) & Yes & Yes & No \\
\hline Chesapeake Bay & $37-38.4^{\circ} \mathrm{N}$ & $76.1^{\circ} \mathrm{W}$ & $\mathrm{Sd}$ & Verardo et al. (1998) & Yes & Yes & - \\
\hline NW Alaska (Farewell L.) & $62.55^{\circ} \mathrm{N}$ & $153.63^{\circ} \mathrm{W}$ & Lf+Is & Hu et al. (2001) & Yes & Yes & No \\
\hline S. Dakota (Pickerel L.) & $45.51^{\circ} \mathrm{N}$ & $97.27^{\circ} \mathrm{W}$ & $\mathrm{Lf}$ & Dean \& Schwalb (2000) & Yes & Yes & No \\
\hline N. Dakota (Moon L.) & $46.85^{\circ} \mathrm{N}$ & $98.16^{\circ} \mathrm{W}$ & Lf & Laird et al. (1996) & Yes & Yes & No \\
\hline N. Dakota (Rice L.) & $48.01^{\circ} \mathrm{N}$ & $101.53^{\circ} \mathrm{W}$ & Lf & Yu \& Ito (1999) & Yes & Yes & No \\
\hline Yellowstone P. (Lamar Cave) & $44.56^{\circ} \mathrm{N}$ & $110.24^{\circ} \mathrm{W}$ & $\mathrm{Pf}+\mathrm{Is}$ & Hadly (1996) & Yes & Yes & No \\
\hline Colorado Plateau (L. Canyon) & $37.42^{\circ} \mathrm{N}$ & $110.67^{\circ} \mathrm{W}$ & $\mathrm{Lf}+\mathrm{Gm}+\mathrm{Is}$ & Pederson $(2000)$ & Yes & Yes & - \\
\hline NE Colorado & $40-41^{\circ} \mathrm{N}$ & $102-105^{\circ} \mathrm{W}$ & $\mathrm{Gm}+\mathrm{Is}+\mathrm{D}$ & Madole (1994) & - & Yes & No \\
\hline SW US (Colorado + Arizona) & $34-37.5^{\circ} \mathrm{N}$ & $105-112^{\circ} \mathrm{W}$ & Lf+Is & Davis (1994) & - & Yes & No? \\
\hline SW US & $32-39^{\circ} \mathrm{N}$ & $109-114^{\circ} \mathrm{W}$ & $\mathrm{Lf}+\mathrm{Gm}$ & Ely et al. (1993) & Yes & Yes & No \\
\hline California (White Mts.) & $37.43^{\circ} \mathrm{N}$ & $118.17^{\circ} \mathrm{W}$ & Is & Feng \& Epstein (1994) & Yes & Yes & - \\
\hline California (L. Owen) & $36^{\circ} \mathrm{N}$ & $118.17^{\circ} \mathrm{W}$ & Is & Li et al. (2000) & Yes & Yes & No \\
\hline $\begin{array}{l}\text { Yucatan Peninsula } \\
\text { (L. Chichancanab) }\end{array}$ & $20^{\circ} \mathrm{N}$ & $88.4^{\circ} \mathrm{W}$ & $\mathrm{Lf}+$ & Hodell & Yes & Yes & - \\
\hline Cariaco Basin & $11^{\circ} \mathrm{N}$ & $65^{\circ} \mathrm{W}$ & Sd & Black et al. (1999) & Yes & Yes & No \\
\hline Cariaco Basin & $10.71^{\circ} \mathrm{N}$ & $65.17^{\circ} \mathrm{W}$ & $\mathrm{Sd}+\mathrm{Is}$ & Haug et al. (2001) & Yes & Yes & - \\
\hline S. Florida & $24.95^{\circ} \mathrm{N}$ & $80.55^{\circ} \mathrm{W}$ & Is & Druffel (1982) & Yes & - & - \\
\hline SW Puerto Rico & $18.12^{\circ} \mathrm{N}$ & $67.09^{\circ} \mathrm{W}$ & Is & Winter et al. (2000) & Yes & - & - \\
\hline NE China (Jinchuan) & $42.3^{\circ} \mathrm{N}$ & $126.37^{\circ} \mathrm{E}$ & Is & Hong et al. (2000) & Yes & Yes & No \\
\hline S. Japan (Yakushima Is.) & $30.33^{\circ} \mathrm{N}$ & $130.5^{\circ} \mathrm{E}$ & Is & $\begin{array}{l}\text { Kitagawa \& } \\
\text { Matsumoto (1995) }\end{array}$ & Yes & Yes & No \\
\hline N. India (Pahalgam) & $34.02^{\circ} \mathrm{N}$ & $75.20^{\circ} \mathrm{E}$ & Is & Ramesh (1993) & Yes & - & - \\
\hline S. India (Nilgiris) & $10-10.5^{\circ} \mathrm{N}$ & $77^{\circ} \mathrm{E}$ & Is & Ramesh (1993) & - & Yes & - \\
\hline E. Africa (L. Malawi) & $10^{\circ} \mathrm{S}$ & $35^{\circ} \mathrm{E}$ & Lf & Johnson et al. (2001) & Yes & - & No \\
\hline E. Africa (L. Naivasha) & $0.46^{\circ} \mathrm{S}$ & $36.21^{\circ} \mathrm{E}$ & Lf & Verschuren et al. (2000) & Yes & Yes & No \\
\hline W. Africa (Cap Blanc) & $20.75^{\circ} \mathrm{N}$ & $18.58^{\circ} \mathrm{W}$ & Is & deMenocal et al. (2000) & Yes & Yes & No \\
\hline S. Africa & $19-35^{\circ} \mathrm{S}$ & $10-33^{\circ} \mathrm{E}$ & Mp & Tyson \& Lindesay (1992) & Yes & Yes & No \\
\hline S. Africa (Nelson Bay Cave) & $34^{\circ} \mathrm{S}$ & $23^{\circ} \mathrm{E}$ & Is & Cohen \& Tyson (1995) & Yes & - & No \\
\hline S. Africa (Makapansgat) & $24.54^{\circ} \mathrm{S}$ & $29.25^{\circ} \mathrm{E}$ & $\mathrm{Sp}$ & Tyson et al. (2000) & Yes & Yes & No \\
\hline N. New Zealand (Waitomo) & $38.27^{\circ} \mathrm{S}$ & $175^{\circ} \mathrm{E}$ & $\mathrm{Sp}$ & Williams et al. (1999) & Yes & - & - \\
\hline S. New Zealand (Nelson) & $40.67^{\circ} \mathrm{S}$ & $172.43^{\circ} \mathrm{E}$ & $\mathrm{Sp}$ & Wilson et al. (1979) & Yes & Yes & No \\
\hline S. America (several regions) & $33-38^{\circ} \mathrm{S}$ & $59.3-67^{\circ} \mathrm{W}$ & $\mathrm{Mp}$ & Iriondo (1999) & Yes & Yes & - \\
\hline C. Argentina & $29.5-35^{\circ} \mathrm{S}$ & $61.75-65.75^{\circ} \mathrm{W}$ & $\mathrm{Gm}+\mathrm{D}$ & Carignano (1999) & Yes & Yes & No \\
\hline C. Argentina & $28-36^{\circ} \mathrm{S}$ & $61-67^{\circ} \mathrm{W}$ & $\mathrm{G}+\mathrm{Mp}$ & Cioccale (1999) & Yes & Yes & No \\
\hline NW Argentina & $26.5^{\circ} \mathrm{S}$ & $68.09^{\circ} \mathrm{W}$ & $\mathrm{Sd}+\mathrm{Is}$ & Valero-Garcés et al. (2000) & Yes & - & - \\
\hline W. Antarctica (Palmer Deep) & $64.86^{\circ} \mathrm{S}$ & $64.21^{\circ} \mathrm{W}$ & $\mathrm{Sd}$ & Domack et al. (2001) & Yes & Yes & No \\
\hline W. Antarctica (Siple Dome) & $81.65^{\circ} \mathrm{S}$ & $148.81^{\circ} \mathrm{W}$ & Is & Kreutz et al. (1997) & Yes & - & No \\
\hline
\end{tabular}

${ }^{a}$ Warming or extreme excursion peaked around 1920-1950 before any signifcant anthropogenic $\mathrm{CO}_{2}$ release to air ${ }^{b}$ Hughes \& Diaz concluded that '[our] review indicates that for some areas of the globe (for example, Scandinavia, China, the Sierra Nevada in California, the Canadian Rockies, and Tasmania), temperatures, particularly in summer, appear to have been higher during some parts of this period than those that were to prevail until the most recent decades of the twentieth century. These regional episodes were not strongly synchronous. Evidence from other regions (for example, the Southeast United States, southern Europe along the Mediterranean, and parts of South America) indicates that the climate during that time was little different to that of later times, or that warming, if it occurred, was recorded at a later time than has been assumed. . . . To the extent that glacial retreat is associated with warm summers, the glacial geology evidence would be consistent with a warmer period in A.D. 900-1250 than immediately before or for most of the following seven hundred years.' The main conclusion of Hughes \& Diaz (1994) may be in actual agreement with the qualitative classifcation in our paper ${ }^{\mathrm{c}}$ Only documentary, historical and archaeological research results, rather than the solar-output model results, of this paper were referred to

${ }^{\mathrm{d}}$ For the Dunde ice cap, Thompson et al. (1989) noted that, according to the $\delta^{18} \mathrm{O}$ climate proxy, the $1940 \mathrm{~s}, 1950 \mathrm{~s}$ and $1980 \mathrm{~s}$ are at least as warm as the Holocene maximum 6000 to 8000 BP. To confrm Thompson et al. (1989) cf. Fig. 6 in Thompson (2000), because the claim that 1930s-1980s are the warmest of the last 6000-8000 yr is not clear from any figure in Thompson et al. (1989). But the main warming of the 1940s-1950s occurred before a significant rise of anthropogenic $\mathrm{CO}_{2}$ in the air 


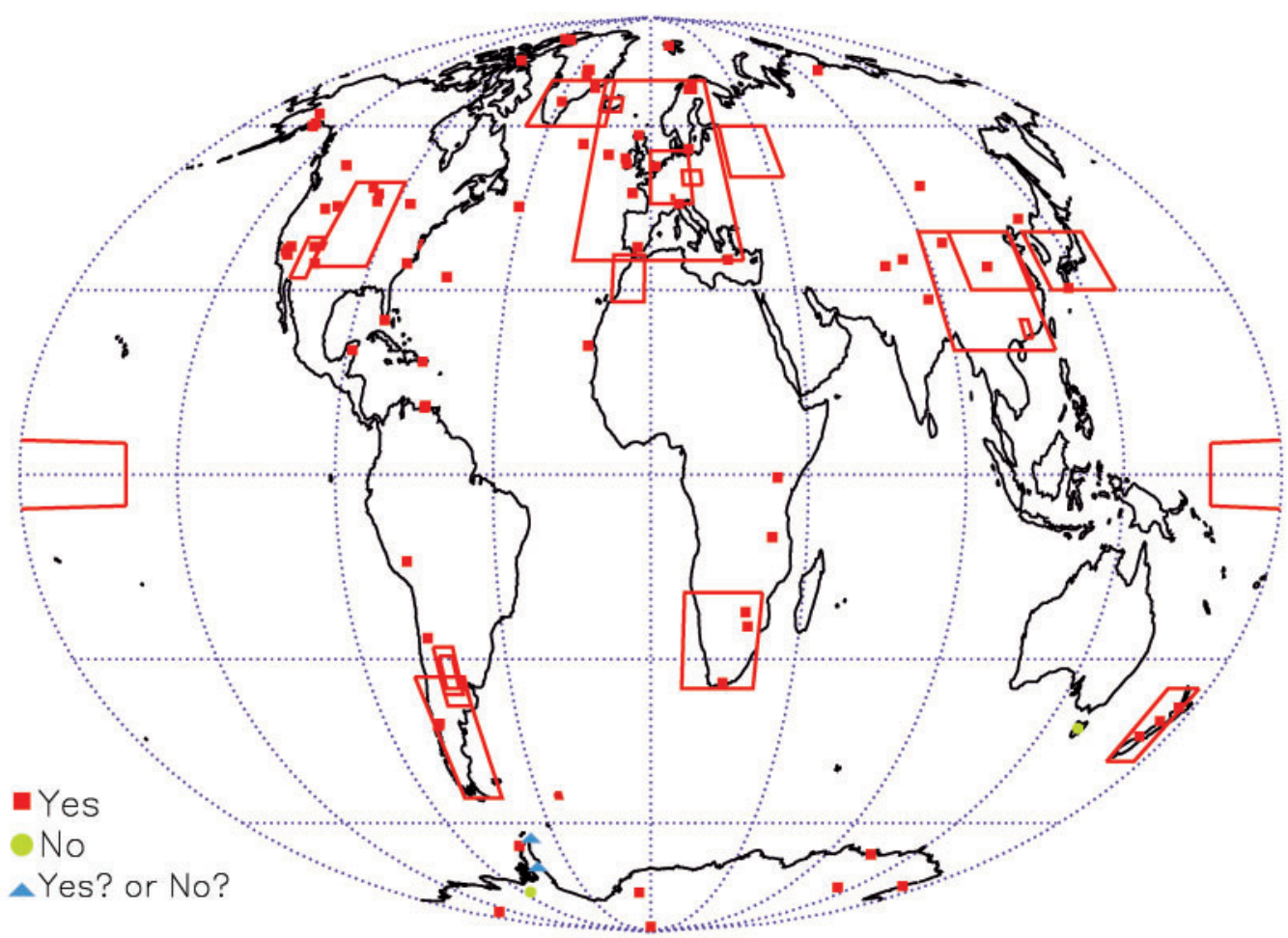

Fig. 1. Geographical distribution of local answers to the following question: Is there an objectively discernible climatic anomaly during the Little Ice Age interval (A.D. 1300-1900) in this proxy record? 'Yes' is indicated by red filled squares or unfilled boxes, 'No' is indicated by green filled circles and 'Yes? or No?' (undecided) is shown with blue filled triangles

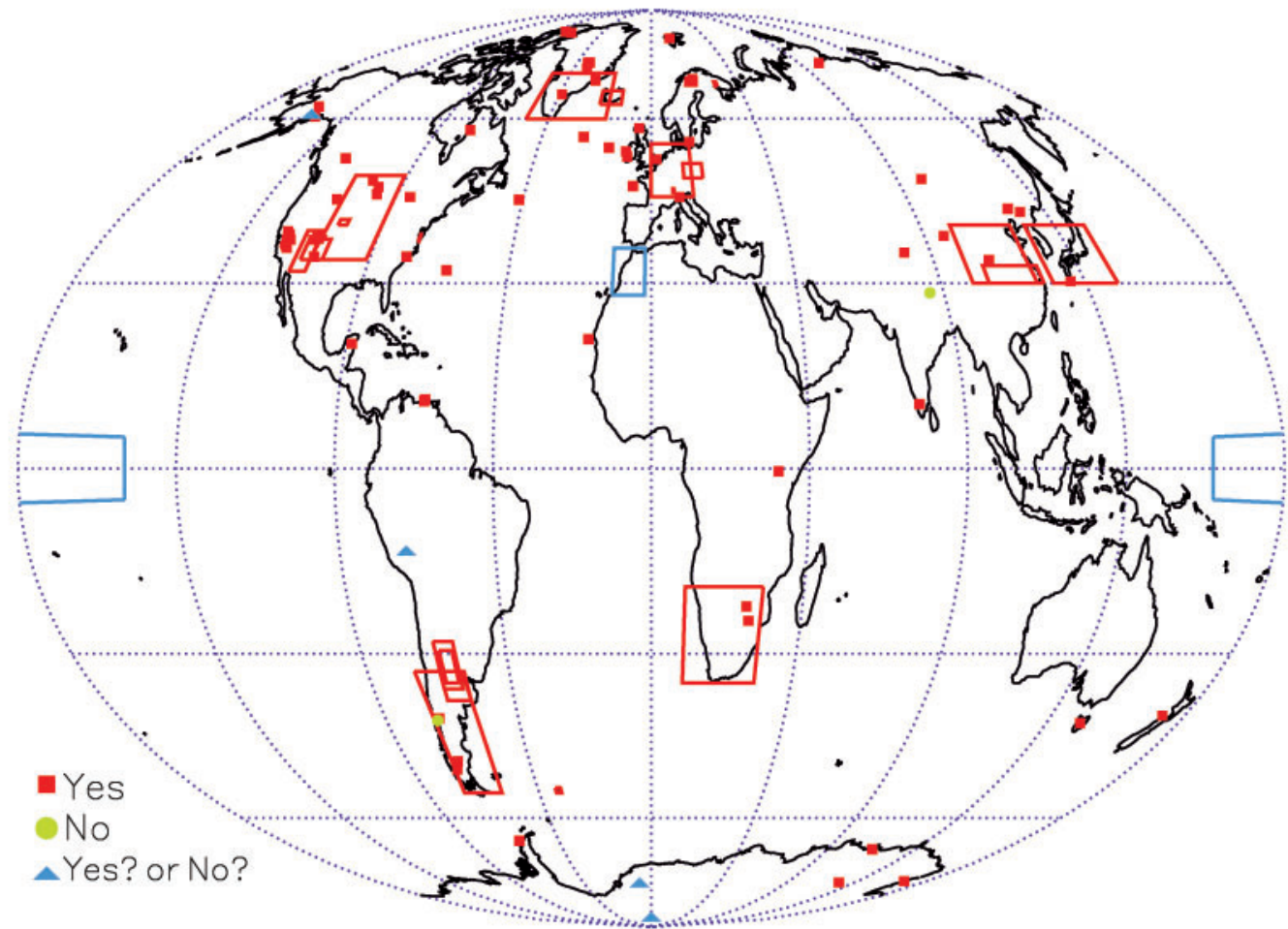

Fig. 2. Geographical distribution of local answers to the following question: Is there an objectively discernible climatic anomaly during the Medieval Warm Period (A.D. 800-1300) in this proxy record? 'Yes' is indicated by red filled squares or unfilled boxes, 'No' is indicated by green filled circles and 'Yes? or No?' (undecided) is shown with blue filled triangles or unfilled boxes 


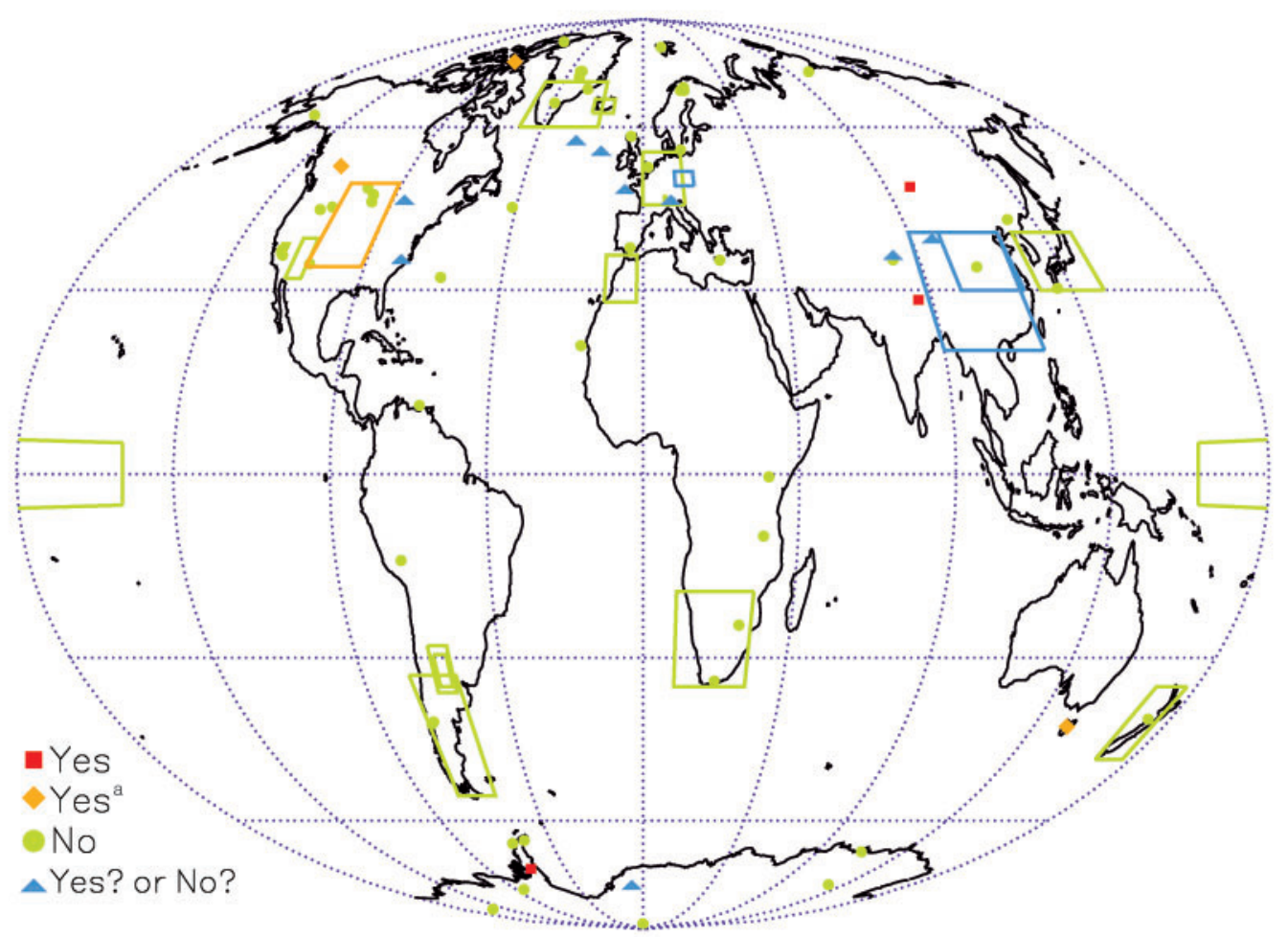

Fig. 3. Geographical distribution of local answers to the following question: Is there an objectively discernible climatic anomaly within the 20th century that is the most extreme (the warmest, if such information is available) period in the record? 'Yes' is indicated by red filled squares, 'No' is indicated by green filled circles or unfilled boxes and 'Yes? or No?' (undecided) is shown with blue filled triangles or unfilled boxes. Answer of ' $\mathrm{Yes}^{\mathrm{a}}{ }^{\prime}$ is indicated by yellow filled diamonds to mark an early to middle-20th century warming rather than the post-1970s warming

The climate indicators considered here include information from documentary and cultural sources, ice cores, glaciers, boreholes, speleothems, tree-growth limits, lake fossils, mammalian fauna, coral and treering growth, peat cellulose; and pollen, phenological and seafloor sediments. In a rather inhomogeneous way, each proxy is influenced by both climatic and non-climatic factors. We rely on individual researchers for their best judgments in interpreting climatic signals. The 3 questions are addressed in the context of local or regional sensitivity of the proxies to relevant climatic variables, including air temperature, sea surface temperature, precipitation, and any combination of large-scale patterns of pressure, wind and oceanic circulation.

\section{UNCERTAINTIES IN INFERRING CLIMATE FROM PROXIES}

The accuracy of climate reconstruction from proxies, including the awareness of anthropogenic interventions that could pose serious problems for a qualitative and quantitative paleoclimatology, has been discussed by Bryson (1985), Idso (1989) and others. The tempera- ture changes inferred for the Medieval Warm and Little Ice Age Climatic Anomalies are generally accepted to be no more than 1 to $2^{\circ} \mathrm{C}$ when averaged over hemispheric or global spatial scale and over decades to a century. Broecker (2001) deduced that only the results from mountain snowline and borehole thermometry are precise to within $0.5^{\circ} \mathrm{C}$ in revealing changes on a centennial timescale. But the quantification of errors is complex, and both Bradley et al. (2001) and Esper et al. (2002) have challenged Broecker's statement. Earlier, Jones et al. (1998) provided an enlightening review of the quantitative and qualitative limitations of paleoclimatology. Others like Ingram et al. (1978) and Ogilvie \& Farmer (1997) had cautioned against the use of quantitative interpretations of climatic results that are based on historical documentation.

In our survey of the literature we have observed 3 distinct types of warnings (Bryson 1985, Clow 1992, Graybill \& Idso 1993, Huang et al. 1996, Briffa et al. 1998, Cowling \& Skyes 1999, Schleser et al. 1999, Evans et al. 2000, Schmutz et al. 2000, Aykroyd et al. 2001, Ogilvie \& Jónsson 2001):

(1) the lack of timescale resolution for the longestterm component of climate signals, e.g. in tree ring and 
coral records, or the loss of short-term climate information in borehole temperature reconstructions;

(2) the nonlinearities (related to age, threshold, discontinuous or insufficient sampling, saturated response, limited dynamic range of proxy, etc.) of biological, chemical and physical transfer functions necessary for temperature reconstruction;

(3) the time dependence or nonstationarity of the climate-proxy calibration relations.

Estimates of ground temperature trends from borehole data can be complicated by non-climatic factors associated with changes in pattern of landuse and land cover over time (Lewis \& Wang 1998, Skinner \& Majorowicz 1999). In general, climate proxies from floral and faunal fossils in lake and bog sediments are only sensitive enough to resolve change to within \pm 1.3 to $1.8^{\circ} \mathrm{C}$ (e.g. Lotter et al. 2000). Isotope-coral proxies lack the climate-sensitivity resolution and the continuous length of record to address millennial climatic change. Jones et al. (1998) showed that both coral- and ice-core-based reconstructions performed more poorly than tree-ring records when calibrated against thermometer data since A.D. 1880. On the other hand, tree ring proxies, which usually have annual time resolution, suffer from the loss of information on multidecadal to centennial and longer components of climate change.

The amplitude of large-scale surface temperature change derived from tree-ring proxies can be substantially underestimated - by a factor of 2 to 3 compared to results from borehole thermometry (Huang et al. 2000, Harris \& Chapman 2001). It is surprising that the amplitude of climate variability broadly resolved by borehole reconstruction on timescales of at least 50 to $100 \mathrm{yr}$ is larger, rather than smaller, than the high time resolution results from tree-ring proxies, because short-term climate fluctuations are smoothed out by the geothermal heat-flow that acts as a low-pass filter. ${ }^{1}$ The different amplitudes found from borehole and tree-ring climate proxies suggest that longer timescale (multi-decades and century) variability is more faithfully captured by borehole results, while the same information can be irretrievably lost from tree-ring records (see e.g. Collins et al. 2002) because of the standardization procedure (to remove bias due to aging of trees). This is why Jones et al. (1998) commented that although one may be confident of intercomparing year-to-year and decade-to-decade (limited to periods shorter than 20 to $30 \mathrm{yr}$ ) variability, which should be more sensitively imprinted in tree-ring

\footnotetext{
${ }^{1}$ There are exceptions in careful tree-ring results like those of Esper et al. (2002) that are optimized to capture longer timescale variability
}

records, it requires 'considerable faith' to compare, for example, the climate of the 12th and 20th centuries from tree-ring proxies. To date, the practical goal of combining information from borehole and tree-ring proxies, or even comparing borehole and thermometer data, to yield an accurate proxy record that simultaneously resolves timescales of years to centuries, remains unfulfilled.

Despite complicating factors such as the mismatch of climate sensitivities among proxies, a first step has been taken by Beltrami et al. (1995) and Harris \& Chapman (2001). Also, Beltrami \& Taylor (1995) successfully calibrated a 2000 yr oxygen isotope record from an ice core (near Agassiz) with the help of borehole temperature-depth data (near Neil) for the Canadian Arctic region. Such careful research may help resolve the difficulty of interpreting climate signals that degrade with borehole depth or time. This depth-dependent, increasing degradation has led to the false impression that reconstructed temperatures from geothermal heat flows contained a significantly smaller variability in the distant past than at present.

The approach used here relies on local representations of climate change, which is an advantage because understanding local proxies is the prerequisite for constructing regional and global patterns of change. Another advantage is that by working with a local or regional perspective, we avoid the difficult questions concerning the spatio-temporal coupling of observed changes among various regions and any specific large-scale pattern responsible for those climatic anomalies. Our study has the disadvantage of being non-quantitative. Thus, our assessment falls short of Lamb's (1965) original call for quantitative answers.

An early attempt to study the interlinkage of geographically separated and different proxies, e.g. between marine sediments at Palmer Deep, Antarctica, and atmospheric signals in Greenland ice cores, has been reported by Domack \& Mayewski (1999). But many chronologies depend on radiocarbon dating and are too limited in accuracy to allow for reliable interpretation of the timing of events from different areas (e.g. Stine 1998, Domack \& Mayewski 1999). The difficult task of areal weighting of different proxy records has been attempted; for the Arctic region by Overpeck et al. (1997), the Northern Hemisphere by Crowley \& Lowery (2000), Northern Hemisphere extratropics by Esper et al. (2002) and both Northern Hemisphere and global domains by Mann et al. (1998, 1999, 2000). However, Briffa et al. (2001) criticized the lack of consideration of uncertainties in some of these reconstructions. For example, the composite series in Overpeck et al.'s (1997) reconstruction is not even calibrated with instrumental data. 


\section{RESULTS}

Table 1 lists the worldwide proxy climate records we have collected and studied. We restricted the list to records that contain either direct information about the 3 specific questions we posed or at least a continuous time series for 400 to 500 yr. For the majority of cases we followed what individual researchers stated according to their paleoclimatic reconstructions. In a few cases we elaborated on their results in order to remain consistent to our framework.

The figures show the results from Table 1 for the Little Ice Age (Fig. 1), Medieval Warm Period (Fig. 2) and the nature of the 20th century's change (Fig. 3). The figures graphically emphasize the shortage of climatic information extending back to the Medieval Warm Period for at least 7 geographical zones: the Australian and Indian continents, the SE Asian archipelago, large parts of Eastern Europe/Russia, the Middle Eastern deserts, the tropical African and South American lowlands (although the large number of available borehole-heat flow measurements in Australia seems adequate for the reconstruction of ground temperatures back to medieval times; see Huang et al. 2000). Therefore, our conclusions are provisional.

Fig. 1 indicates that Little Ice Age exists as a distinguishable climate anomaly from all regions of the world that have been assessed. Only 2 records - tree ring growth from western Tasmania and isotopic measurements from ice cores at Siple Dome, Antarcticado not exhibit any persistent climatic change over this period (although the western Tasmania reconstruction contains an exceptionally cold decade centered around 1900; Cook et al. 2000).

Fig. 2 shows the Medieval Warm Period with only 2 negative results. The Himalayan ice core result (Thompson et al. 2000) seems unambiguous, but the tree-ring proxy data from Lenca, southern Chile (Lara \& Villalba 1993) is countered by nearby evidence of the Medieval Warm Period (Villalba 1990, 1994).

Fig. 3 shows that most of the proxy records do not suggest the 20th century to be the warmest or the most extreme in their local representations. There are only 3 unambiguous findings favoring the 20th century as the warmest anomaly of the last $1000 \mathrm{yr}$ - the records from the Dyer Plateau, Antarctica, the Himalayas and Mongolia (Thompson et al. 1994, 2000, D'Arrigo et al. 2001). An important, seemingly counter-intuitive, feature of Fig. 3 is the large number of uncertain answers compared to the 2 prior questions, perhaps partly owing to inaccurate calibration between proxy and instrumental data. Also, another feature of the result is the many cases in which the warmest or most extreme climatic anomalies in the proxy indicators occurred in the early to mid-20th century ('Yes $\left.{ }^{\mathrm{a} \prime}\right)$, rather than sustaining throughout the century.

\subsection{Glaciers}

Broadly, glaciers retreated all over the world during the Medieval Warm Period, with a notable, but minor, re-advance between 1050 and 1150 (Grove \& Switsur 1994). Large portions of the world's glaciers, both in the Northern and Southern Hemispheres, advanced during the 1300 to 1900 s (Grove 2001b, see also Winkler 2000). The world's small glaciers and tropical glaciers have simultaneously retreated since the 19th century, but some glaciers have advanced (Kaser 1999, Dyurgerov \& Meier 2000, D. Evans 2000). Kaser (1999) reemphasized the key role played by atmospheric humidity in controlling the net accumulation and ablation of glaciers by modulating the sublimation and long-wave radiative forcing-feedback budgets in both dry and humid areas. So far, the proposition of the 20th century warming as a natural recovery since the Little Ice Age, together with an amplification by anthropogenic $\mathrm{CO}_{2}$, is plausible but not definitive (Bradley \& Jones 1993, Kreutz et al. 1997, Kaser 1999, Beltrami et al. 2000, Dyurgerov \& Meier 2000). On the other hand, D. Evans (2000) discussed the possibility of recent widespread recession of glaciers as a glacioclimatic response to the termination of the Little Ice Age and commented that significant warming phases during interglacials, especially those accompanied by relatively warm winters and cool summers, may lead to the onset of another global glaciation.

Additional proxy records used here reveal that the climatic anomaly patterns known as the Medieval Warm Period (ca. A.D. 800-1300) as well as the Little Ice Age interval (A.D. 1300-1900) occurred across the world. The next 2 subsections describe detailed local changes in the Northern and Southern Hemispheres.

\subsection{Northern Hemisphere}

A composite reconstruction of summer temperature anomaly assuming a simple, uniform weighting of proxy records by Bradley \& Jones (1993) showed that the 1530-1730 interval was the coldest period for the Northern Hemisphere, and the 19th century was the second coldest interval in the last 500 yr.

\subsubsection{Western Europe}

Cold winters and wet summers prevailed during the Little Ice Age in Switzerland, a location with detailed and reliable information (Pfister 1995). A careful comparison of the Swiss and central England temperature records (Manley 1974) from 1659-1960 reveals a general correspondence of climatic conditions between the 2 
regions. In the Andalusia region of southern Spain, rainfall appears to have alternated between dry and wet century-long spells (wet periods persisted 1590-1649 and 1776-1937; dry periods 1501-1589 and 1650-1775) throughout the Little Ice Age, and with no significant difference to the modern dry period of 1938-1997 (Rodrigo et al. 2000). Enhanced fluvial activity was documented in river basins of North, Western and Central Europe for 1250-1550 and 1750-1900 (A. T. Grove 2001). Over Western Europe, Pfister et al. (1998) concluded that severe winters were less frequent and less extreme during 900-1300 than those during 1300-1900. The mild-winter condition was hypothesized by Pfister et al. (1998) to have caused the northward migration of Mediterranean subtropical plants, where St. Albertus Magnus noted the abundance of pomegranates and fig trees in the 13th century around Cologne and parts of the Rhine valley. Olive trees, which, like fig trees, are also sensitive to prolonged periods of air temperature below freezing, must have grown in Italy (Po valley), France and Germany because a chronicler documented the damage to the olive trees by the bitter frost in January 1234. Lamb (1965) noted generally wet winters but drier summers for the lowlands in England, Ireland, the Netherlands, Denmark, Sweden and NW Germany from about 1200 to 1400 . Those conditions are supported by documentary records that describe frequent flooding and storms around those regions during the transitional period between Medieval Warm Period and Little Ice Age.

Is the warmth of the 20th century for western Europe exceptional or unusual? Weather reconstruction results for the Low Countries, the present-day Benelux region, suggest that in order to compare the 20th century to previous centuries, seasonal information in a proxyclimate relation will be required (van Engelen et al. 2001). For example, van Engelen et al. (2001) showed that when the historical reconstructed series from about 800 to 2000 were calibrated to the instrumental temperature records at De Bilt, the 20th century winter temperatures may have been slightly higher (about $0.5^{\circ} \mathrm{C}$ - the quantitative information on the 20th century warmth is certainly within the margin of uncertainties) than the high winter temperatures of 1000-1100 but that recent warming began in the 19th century. In contrast, the 20th century summer temperatures are neither unusual nor extraordinarily warm when compared to summer temperature variabilities during other times of the 2nd millennium (see Figs. 1 \& 2 of van Engelen et al. 2001).

\subsubsection{North Atlantic and other oceans}

During the Little Ice Age, extensive areas around Mediterranean Europe and the North Atlantic, includ- ing Western and Northern Europe, Greenland and Iceland, were experiencing unusually cold and wet conditions as well as many extreme weather events, including deluges, landslides and avalanches (Grove 1996, Ogilvie et al. 2000, A. T. Grove 2001). Climate over Iceland was found, based on various proxies, to be mild from 870 to 1170 , with cold periods setting in after 1200. Instead of being a period of unrelenting cold, Ogilvie (1984) emphasized that the most notable aspect of climate over Iceland during the 17th to 19th centuries, with its very cold decades during the 1690 s, 1780 s, 1810 s and 1830s, was its large year-to-year variability (see also Ogilvie \& Jónsson 2001).

The viking colonization of Greenland's coastal area starting in 986 is well documented, and the generally mild and benign climatic conditions from about 800 to 1200 that helped to sustain the settlement, are also well supported by ice core and borehole proxy information (Dansgaard et al. 1975, Dahl-Jensen et al. 1998). The Norsemen's 'Western Settlement' (around the Godthab district) was mysteriously abandoned sometime between 1341 and 1362, while the 'Eastern Settlement', actually near the southernmost tip of west Greenland, around the Narssaq and Julianehab districts, died out between 1450 and 1500 (Grove 1996, Ogilvie et al. 2000). It also seems that both cultural and political factors contributed in making the Norse Greenlanders at the Western Settlement more vulnerable to the harsh climatic conditions (Barlow et al. 1997). The timing for the abandonment of these settlements coincided with the general cooling over Greenland, as established by both ice-core isotopic and borehole thermometry (Dansgaard et al. 1975, Stuiver et al. 1995, Dahl-Jensen et al. 1998). From sediment cores near Nansen Fjord, East Greenland, Jennings \& Weiner (1996) confirmed an initial cooling between 1270 and 1370 , together with the most severe and variable climatic conditions around the East Greenland region from 1630 to 1900 . The results of Ogilvie et al. (2000) and Ogilvie \& Jónsson (2001) suggest that the overall climatic conditions in the North Atlantic $\left(50-80^{\circ} \mathrm{N}, 0-60^{\circ} \mathrm{W}\right)$, especially near Iceland during the 20th century, including the 1970 s to 1990 s, were neither unusual nor extreme.

In the Mediterranean basin, the island of Crete experienced many severe winters and prolonged droughts during the winter and spring seasons between 1548 and 1648 (Grove \& Conterio 1995). In Morocco, the climate during the 16th, 17 th and 18th centuries was generally more variable, with frequently drier conditions, than in the early to mid-20th century (Till \& Guiot 1990). But no distinctive precipitation anomaly was observed for Morocco during the Medieval Warm Period, although just like conditions during the Little Ice Age, an episode of notable drought occurred from 1186 to 1234 . Thus, precipitation anomalies for the Little Ice Age and Medieval Warm Period do not differ 
from each other in this region-both intervals suffered from persistent drought conditions. For this reason, we gave an uncertain designation for the occurrence of a distinct climatic anomaly associated with Medieval Warm Period for Morocco in Table 1 and Fig. 2.

Distinctly cooler conditions prevailed over the ocean surface - in the Caribbean Sea by about 2 to $3^{\circ} \mathrm{C}$ (Winter et al. 2000) and in the Sargasso Sea by about $1^{\circ} \mathrm{C}$ (Keigwin 1996), especially during the 17 th and 18th centuries as opposed to the present. DeMenocal et al. (2000) showed that the subtropical North Atlantic's sea surface temperature off Cap Blanc of Mauritania (west Africa) was also cooler by 3 to $4^{\circ} \mathrm{C}$ between 1300 and 1850 than at present. During the Medieval Warm Period, the Sargasso sea surface temperature was about $1{ }^{\circ} \mathrm{C}$ warmer than the present-day value (Keigwin 1996), while the sea surface temperature off the coast of Mauritania was only marginally warmer than at present (DeMenocal et al. 2000). High-resolution coral skeletal $\delta^{18} \mathrm{O}$ and Sr/Ca ratio records from Bermuda indicate sea-surface temperature standard deviations of about $\pm 0.5^{\circ} \mathrm{C}$ on interannual and $\pm 0.3^{\circ} \mathrm{C}$ on decadal timescales during the 16 th century, and those ranges of variability are comparable to estimates from modern 20th century's instrumental data (Kuhnert et al. 2002). But those sub-annually resolved coral proxy data also show that although there may be large-scale climate signals like the North Atlantic Oscillation detectable at Bermuda, no correlation can be found with other northern-hemisphericwide proxy reconstructions because of large spatial differences in climate variability.

From sedimentary concentrations of titanium and iron, Haug et al. (2001) inferred a very dry climate for the Cariaco Basin during the Little Ice Age and relatively wetter conditions in the Medieval Warm Period. Over the equatorial Central Pacific, around the NINO3.4 $\left(5^{\circ} \mathrm{N}-5^{\circ} \mathrm{S}, 160^{\circ} \mathrm{E}-150^{\circ} \mathrm{W}\right)$ region, Evans et al. (2000), in their skillful reconstruction of the ENSOlike decadal variability of the NINO3.4 sea surface temperature (SST), showed that there appeared to be a sustained cool phase of the proxy NINO3.4 SST variability from about 1550 to about 1895, hence extending the geographical area covered by the Little Ice Age Climate Anomaly. Evans et al. (2000) also added that the reconstructed NINO3.4 decadal-scale SST variability prior to the 17 th century is similar to that of the 20th century, thus suggesting that the recent 20th century decadal-scale changes in the equatorial Pacific Ocean are neither unusual nor unprecedented.

\subsubsection{Asia and Eastern Europe}

From 49 radiocarbon-dated subfossil wood samples, Hiller et al. (2001) found that the alpine tree-limit on the Khibiny low mountains of the Kola Peninsula was located at least 100 to $140 \mathrm{~m}$ above current tree-limit elevation during the relatively warmer time between 1000 and 1300. The summer temperatures corresponding to this tree-line shift during this warm time are estimated to have been at least $0.8^{\circ} \mathrm{C}$ warmer than today. Based mostly on documentary evidence, Borisenkov (1995) noted that Little Ice Age conditions began as early as the 13th century in Russia with the characteristic of frequent climate extremes both in terms of severe winters, rainy and cool summers, and sustained droughts (up to a decade long). Middle Russia (around $50-60^{\circ} \mathrm{N}$ and $30-50^{\circ} \mathrm{E}$ ) seems to have experienced the coolest winters around 1620-1680, the coolest summers-springs around 1860-1900, as well as distinctively warm conditions during the first half of the 16th century, similar to conditions for Western Europe described above. The ground surface temperature histories deduced from boreholes around the Czech Republic suggest that winters during 1600 and 1700 were the most severe compared to any other winters since at least 1100 (Bodri \& Cermák 1999). The temperature-depth borehole records also yield a clear signature of an anomalously warm period for central Bohemia, especially around 1100-1300.

Bradley and Jones (1993) showed that the mid-17th century was the coldest in China. In NE China, frequent occurrences of extremely dry conditions prevailed during the 16th and 17th centuries (Song 2000). The dry conditions returned again in the 20th century, and now cover a wider area (with indications including the increasing number of days with no discharge from the Yellow River; but these 20th-century events are likely to be confused with other man-made factors). Chan \& Shi (2000) further documented the notably larger number of land-falling typhoons over Guandong Province in the early-to-mid-19th century based on a homogeneous set of typhoon records from 1470 to 1931. Using a $\delta^{18} \mathrm{O}$ proxy record from peat cellulose with $20 \mathrm{yr}$ resolution and various Chinese historical records, Hong et al. (2000) showed the general cooling trend in the surface air temperature during the Little Ice Age interval in NE China. Hong et al. found 3 of the coolest minima in the record centered around 1550, 1650 and 1750. An obvious warm period peaked around 1100-1200, coinciding with the Medieval Warm Period. The study of documented cultivation of Citrus reticulata Blanco (a citrus tree) and Boehmeria nivea (a perennial herb), both subtropical and temperature-sensitive plants, during the last 1300 yr showed that northern boundaries for these plants had shifted and expanded; their northernmost location was reached around 1264 (Zhang 1994). Zhang then deduced that temperature conditions in the 13th century around central China must have been about $1^{\circ} \mathrm{C}$ 
warmer than present. Ren (1998) found further evidence from a fossil pollen record at Maili Bog, NE China, that summer monsoon rainfall from 950 to 1270 must have been generally more vigorous in order to explain the high deposition of several pollen taxa, which are otherwise unexplainable by human activity at those times.

Based on the less precise climate proxies like cherry blossom viewing dates, lake freezing dates and historical documentation of climate hazards and unusual weather, Tagami $(1993,1996)$ found that a warm period prevailed between the 10th and 14th centuries, and a cold period between the late 15th and 19th centuries over large parts of southern Japan. From the study of number of days with snowfall relative to days with rainfall, Tagami (1996) concluded that the 11th and 12th centuries were unusually warm in Japan. During the Little Ice Age, summers were relatively cool from the 1730 s to $1750 \mathrm{~s}$, in the $1780 \mathrm{~s}$, from the 1830 s to the 1840s and in the 1860s, and winters were cold through the 1680 s to $1690 \mathrm{~s}$, and in the 1730 s and 1810s. From the tree-cellulose $\delta^{13} \mathrm{C}$ record of a giant Japanese cedar Cryptomeria japonica grown on Yakushima Island of southern Japan, Kitagawa \& Matsumoto (1995) inferred a cool temperature of $2{ }^{\circ} \mathrm{C}$ below average from 1600 to 1700 and a warm period of about $1^{\circ} \mathrm{C}$ above average between 800 and 1200 .

\subsubsection{North America}

Overall, the composite summer temperature anomaly from Bradley \& Jones (1993) showed that over North America the temperature during the 15th to 17th centuries was $1{ }^{\circ} \mathrm{C}$ cooler than the average of the reference period 1860-1959. Over the southern Sierra Nevada, California, Graumlich (1993) found that the coolest $50 \mathrm{yr}$ interval in the $1000 \mathrm{yr}$ tree-ring proxy record was around 1595-1644, while the wettest $50 \mathrm{yr}$ period was 1712-1761. These periods are consistent with our definition of a discernible climatic anomaly associated with the Little Ice Age interval of 1300-1900. Ely et al. (1993) noted from river records in Arizona and Utah that the most extreme flooding events occurred during transitions from cool to warm climate conditions, especially during the late 1800 s to early 1900s. For the Central U.S.A. $\left(33-49^{\circ} \mathrm{N}, 91-109^{\circ} \mathrm{W}\right)$, drought episodes were noted for the 13th to 16th centuries (Woodhouse \& Overpeck 1998). These droughts were of longer duration and greater extent than the 1930s-1950s drought. Additionally, both $\mathrm{Yu}$ \& Ito (1999) and Dean \& Schwalb (2000) pointed to the cycles of aridity lasting about $400 \mathrm{yr}$ from lake records of the Northern Great Plains, where the last dry condition peaked around 1550-1700.
From an extensive collection of multiproxy evidence, Stine (1998) concluded that during the Medieval Warm Period prolonged intervals of extreme drought visited California, the NW Great Basin, the northern Rocky Mountains/Great Plains, while markedly wetter regimes persisted in the upper Midwest/sub-Arctic Canada and Southern Alaska/British Columbia areas. There was also a significant but brief interval around 1110-1140 when moisture conditions switched from dry to wet in California, the NW Great Basin, the northern Rocky Mountains/Great Plains, and from wet to dry in the upper Midwest/sub-Arctic Canada and southern Alaska/British Columbia. The most likely explanation for this rapid and dramatic switch from wet to dry conditions in the upper Midwestern U.S. around 1100 is the contraction and subsequent expansion of the circumpolar vortex. Summer polar fronts shifted significantly southward, and stopped the penetration of moisture-laden air from the Gulf of Mexico (Bryson et al. 1965). Stine (1998) added the requirement of a concomitant jet-stream change, from zonal to azonal, in order to explain the distinct observed differences of the moisture patterns between the upper Midwest and southern Alaska/British Columbia. Graumlich (1993)'s reconstruction of summer temperature and winter precipitation from trees in the Sierra Nevada confirmed the overall warm and dry conditions for California during medieval times, when the 2 warmest and the 2 driest $50 \mathrm{yr}$ intervals occurred, at 1118-1167, 1245-1294 and 1250-1299, 1315-1364, respectively.

Hu et al. (2001), based on their high-resolution (multidecadal) geochemical analysis of sediments from Farewell Lake by the NW foothills of the Alaska Range, also found pronounced signatures of the Medieval Warm Period around 850-1200. During the Little Ice Age the surface water temperature of Farewell Lake suffered a low in 1700 calibrated to be about $1.75^{\circ} \mathrm{C}$ cooler than present. They also noted that colder periods were in general wetter (in contrast to drier conditions during Little Ice Age in the Central U.S. region described above) than the warm periods in this part of NW Alaska. On the Yucatan Peninsula, prolonged drought episodes recur approximately every $208 \mathrm{yr}$, with the 2 most significant recent peaks centered around 800 and 1020 (Hodell et al. 2001). The timing of severe droughts also seems to fit several known discontinuities in the evolution of the Mayan culture.

\subsection{Southern Hemisphere}

Figs. 1-3 highlight the sparse coverage of the Southern Hemisphere by proxy climatic information through the 2nd millennium. 


\subsubsection{New Zealand}

In New Zealand, the $\delta^{18} \mathrm{O}$ concentration in a stalagmite record from a cave in NW Nelson showed the coldest times during the Little Ice Age to be around 1600-1700, while exceptionally warm temperatures occurred around 1200-1400, in association with the general phenomenology of the Medieval Warm Period (Wilson et al. 1979). The cooling anomaly around 1600-1700 apparent in the $\delta^{18} \mathrm{O}$ stalagmite record coincides with the smallest growth ring (i.e. coolest period) for the silver pine Lagarostrobus colensoi from Mangawhero of the North Island. However, at Ahaura in the South Island, the smallest ring width index of the 600 yr record occurred about 1500-1550 (D'Arrigo et al. 1998). Williams et al. (1999) advise caution in interpreting stable isotope data from New Zealand, especially the correctional functional relations among temperature, precipitation and $\delta^{18} \mathrm{O}$ data (which are strongly influenced by oceans surrounding New Zealand) from Waitomo, North Island's speleothems. The mean annual temperatures at Waitomo from 1430-1670 were deduced, based on the analysis of $\delta^{18} \mathrm{O}$ data from Max's cave stalagmite, to be about $0.8^{\circ} \mathrm{C}$ cooler than today.

\subsubsection{South Africa}

Tyson et al. (2000) showed through isotopic measurements in speleothem that the interior region of South Africa, near the Makapansgat Valley (eastern part of South Africa), had a maximum cooling of about $1^{\circ} \mathrm{C}$ around 1700 compared to the present. This cooling feature corresponds well with the maximum cooling signal contained in a coral record from SW Madagascar (Tyson et al. 2000). Tyson \& Lindesay (1992) showed that the Little Ice Age in South Africa had 2 major cooling phases, around 1300-1500 and 1675-1850, with a sudden warming interval between 1500 and 1675. In addition, Tyson \& Lindesay suggested a weakening of the tropical easterlies that increased the incidence of drought during the Little Ice Age in South Africa - with a relatively drier condition for the summer rainfall region in the northeast, but a wetter condition for the winter rainfall region near the coastal Mediterranean zone in the southwest. At Makapansgat Valley, the Medieval Warm Period peaked with a temperature about $3-4^{\circ} \mathrm{C}$ warmer than present around $1200-1300$ (Tyson et al. 2000). The multiproxy review by Tyson \& Lindesay (1992) showed evidence for a wetter South Africa after 1000, when forest and wetland become more extensive, including the development of a riverine forest in the northern Namib desert along the Hoanib river during the 11 th-13th centuries.

\subsubsection{South America}

Over southern South America's Patagonia, the Little Ice Age's climatic anomalies, as deduced from tree ring records, were manifest as cold and moist summers with the most notable, persistent century-long wet intervals centered around 1340 and 1610 (Villalba 1994). From a multiproxy study of lacustrine sediments at Lake Aculeo (about $34^{\circ} \mathrm{S} ; 50 \mathrm{~km}$ southeast of Santiago, Chile), Jenny et al. (2002) found a period of greatly increased flood events centered around 1400-1600 (and in 3 other intervals: 200-400, 500-700 and 1850-1998), which could be interpreted as increased winter rains from enhanced mid-latitude westerlies that ushered in more frontal system activities. In contrast, during the Medieval Warm Period, the southern Patagonia region at latitudes between 47 and $51^{\circ} \mathrm{S}$ became abnormally dry for several centuries before 1130 when water levels in several lakes (Lake Argentino, Lake Cardiel and Lake Ghio) dropped significantly. Also, trees like the southern beech Nothofagus sp. grew as old as $100 \mathrm{yr}$ in the basin of these lakes before being killed by reflooding of the lakes (Stine 1994).

Slightly north toward the central region of Argentina (around Córdoba Province), Carignano (1999), Cioccale (1999) and Iriondo (1999) noted the prevailing conditions for the advancement of the Andean glaciers during the Little Ice Age, with 2 distinct cold and dry intervals around the 15 th to 16 th, and the 18 th to the early 19 th centuries. The significant climate aridification and deterioration in central Argentina (in contrast to the more humid conditions and increased flood frequency in central Chile near Lake Aculeo) during the Little Ice Age interval is supported by the formation of large, parabolic sand dunes 150-200 $\mathrm{m}$ long, 60-80 $\mathrm{m}$ wide, and 2-3 m high in the Salinas Grandes basin (Carignano 1999). Meanwhile the Mar Chiquita Lake was transformed into a swamp surrounded by dunes in the 18th century. Today Mar Chiquita is the largest lake in Argentina, covering a surface area of $6000 \mathrm{~km}^{2}$ and with a depth of $13 \mathrm{~m}$ (Iriondo 1999). The climatic conditions during the Medieval Warm Period around Central Argentina were generally warmer and more humid than at other times in the 2nd millennium, when the dune fields were conquered by lakes and the Mar Chiquita Lake expanded beyond its present dimensions. Precipitation exceeded current values, and the mean local temperature may have been about $2.5^{\circ} \mathrm{C}$ warmer, perhaps because of the southward shift of the tropical climate belt into this area (Iriondo 1999). The northern part of Córdoba Province was invaded by the eastern boundary of the Chaco Forest, which is located hundreds of kms to the northwest today (Carignano 1999). Cioccale (1999) noted evidence of human cultivation of hillside areas in Central Andes, Peru, at places as high as $4300 \mathrm{~m}$ above sea level around 1000. 


\subsubsection{Antarctica}

The last important source of geographical information for conditions during the Medieval Warm Period and the Little Ice Age in the southern hemisphere is obtained from glaciers, ice cores and sea sediments studies on and around Antarctica. Although many notable physical, biological and environmental changes have recently occurred there, especially around the Antarctic Peninsula during the last 50 yr (Mercer 1978, Thomas et al. 1979, Rott et al. 1996, Vaughan \& Doake 1996, Smith et al. 1999, Doran et al. 2002, Marshall et al. 2002), most of the 20th-century changes contained in the proxy records discussed here cannot be considered extreme or unusual (see Fig. 3, also Vaughan \& Doake 1996, D. Evans 2000).

For the Little Ice Age, advances of glaciers in South Georgia Island, which is currently half-covered by glaciers, began after the late 13th century, with a peak advancement around the 18th-20th centuries (Clapperton et al. 1989). Glacier retreats occurred after about 1000, which corresponds to the timing for the Medieval Warm Period. Baroni \& Orombelli (1994) described a similar sequence for glacier advances and retreats during the Little Ice Age and Medieval Warm Period for the Edmonson Point glacier at the Terra Nova Bay area of Victoria Land on the Antarctic continent (East Antarctica). The Edmonson Point glacier retreated in 2 distinct phases, around 920-1020 and 1270-1400, and then advanced at least $150 \mathrm{~m}$ after the 15th century. Isotopic thermometry from ice cores at Dome $\mathrm{C}\left(74.65^{\circ} \mathrm{S}, 124.17^{\circ} \mathrm{E}\right.$, elevation $\left.3240 \mathrm{~m}\right)$ and Law Dome $\left(66.73^{\circ} \mathrm{S}, 112.83^{\circ} \mathrm{E}\right.$, elevation $\left.1390 \mathrm{~m}\right)$ both indicate cooler and warmer anomalies for the Little Ice Age and Medieval Warm Period respectively (Benoist et al. 1982, Morgan 1985). High-resolution records of magnetic susceptibility from deep sea cores (Domack \& Mayewski 1999, Domack et al. 2001) drilled near Palmer Deep site $\left(64.86^{\circ} \mathrm{S}, 64.21^{\circ} \mathrm{W}\right)$ off the Antarctic Peninsula also show a marked increased, in bioproductivity, hence a decrease in magnetic susceptibility because of dilution of the magnetite, with a peak centered around 1000-1100 yr BP. This observation probably implied warm temperatures and minimal sea-ice conditions, coinciding with the Medieval Warm Period. In the same record, Domack and colleagues found a decrease in bio-productivity, hence an increase in magnetic susceptibility owing to less dilution of the magnetic minerals by biogenic materials, from about 700 to $100 \mathrm{yr}$ BP. This time period corresponds to the Little Ice Age of ca. 14th-19th centuries and is likely to have been accompanied by cool and windy conditions. Abundance analyses of $\mathrm{Na}+$ sea salt in the ice core from Siple Dome $\left(81.65^{\circ} \mathrm{S}, 148.81^{\circ} \mathrm{W}\right)$ also confirm the Little Ice Age anomaly characterized by substantial variability in the strength of meridional circulation that extended between 1400 and 1900 (Kreutz et al. 1997).

But there are also indications for significant regional differences in climatic anomalies associated with the 2 phenomena at Antarctica. The temperature at Siple Station $\left(75.92^{\circ} \mathrm{S}, 84.25^{\circ} \mathrm{W}\right.$, elevation $\left.1054 \mathrm{~m}\right)$ was relatively warm from the 15 th to early 19 th centuries (although there were also noticeable decade-long cooling dips centered around 1525, 1600 and 1750; Mosley-Thompson 1995). The $400 \mathrm{yr}$ isotopic temperature inferred from a core at the Dalinger Dome $\left(64.22^{\circ} \mathrm{S}, 57.68^{\circ} \mathrm{W}\right.$, elevation $\left.1640 \mathrm{~m}\right)$ on James Ross Island, off the Antarctic Peninsula, also showed 1750-1850 to be the warmest interval, followed by a cooling of about $2^{\circ} \mathrm{C}$ since 1850 and continuing to 1980 (Aristarain et al. 1990). A recent borehole temperature reconstruction from Taylor Dome, east Antarctica $\left(77.8^{\circ} \mathrm{S}, 158.72^{\circ} \mathrm{E}\right.$, elevation $\left.2374 \mathrm{~m}\right)$, also reported the same inverted temperature anomalies, during which the Little Ice Age interval was about $2{ }^{\circ} \mathrm{C}$ warmer, while the coldest temperature of the past $4000 \mathrm{yr}$ was reached around 1000 (Clow \& Waddington 1999); note that we have omitted these discussions in our Table 1 or Figs. 1 to 3 because the results are claimed as preliminary and they were only presented in a conference abstract.

\section{DISCUSSION}

The widespread geographical evidence assembled here supports the existence of both the Little Ice Age and the Medieval Warm Period, and should serve as useful validation targets for any reconstruction of global climate history of the last $1000 \mathrm{yr}$. Our results suggest a different interpretation of the multiproxy climates compared to recent conclusions of Mann et al. (1998, 1999, 2000). Because the calibration of proxy indicators to instrumental data is still a matter of openended research (with differing sensitivities not only for the same proxy at different locations but also for different proxies at the same location), it is premature to select a year or decade as the warmest or coldest in a multiproxy-based record.

Barnett et al. (1999) has pointed out that it is impossible to use available instrumental records to provide estimates for the multi-decadal and century-long type of natural climatic variations, owing to the specific period and short duration of instrumental records. Thus, paleo-proxies remain the only hope for assessing the amplitude and pattern of climatic and environmental change in the pre-anthropogenic era. We agree with Barnett et al. (1999) that each proxy should be studied first in terms of local change before several records can be combined for regional and larger spa- 
tial-scale analyses and interpretations. The conclusion derives mainly from the real possibility of non-stationarity in the proxy-climate calibration to instrumental records, the lack of adequate superposition rules given variability in each type of proxy, as well as the lack of clear physical understanding on the multidecadal climate variability from theoretical or empirical studies.

All current calibration of proxies to large-scale instrumental measurements have been mainly valid over phases of rising temperature (Ogilvie \& Jónsson 2001). The concern is that a different calibration response arises when the procedure is extended to an untested climate regime associated with a persistent cooling phase. Evans et al. (2002) worried about the reality of spurious frequency evolution that may contaminate a multiproxy reconstruction, in which the type of proxy data changes over time and no sufficient overlap of proxy data exists for a proper inter-proxy calibration/validation procedure. In other words, each proxy may have its distinct frequency response function, which could confuse the interpretation of climate variability. Finally, another concern is the lack of understanding of the air-sea relationship at the multidecadal timescale, even in the reasonably well observed region of the North Atlantic (Häkkinen 2000, Seager et al. 2000, Marshall et al. 2001, Slonosky \& Yiou 2001, von Storch et al. 2001).

Briffa (2000) concluded that dendroclimatological records may support 'the notion that the last 100 years have been unusually warm, at least within the context of the last two millennia' Slightly later, Briffa et al. (2001), by adopting a new analysis procedure that seeks to preserve greater, long timescale variability (which shows a notable increase in variance at the 24-37 yr timescale compared with a previous standardization procedure) in their tree-ring density data than previously possible, stated that the 20th century is the globally warmest century of the last $600 \mathrm{yr}$. This conclusion is consistent with the borehole reconstruction results of Huang et al. (2000). However, longer and more carefully reconstructed tree-ring chronologies from Esper et al. (2002) showed that the Medieval Warm Period was as warm as the 20th century for at least a region covering the Northern Hemisphere extratropics from about 30 to $70^{\circ} \mathrm{N}$.

An important aspect of both the Briffa et al. (2001) and Esper et al. (2002) studies is the new derivation of formal, time-dependent standard errors for their temperature reconstructions, amounting to about \pm 0.1 to $0.3^{\circ} \mathrm{C}$ from 1000 through 1960 (see also Jones et al. 1999, 2001). This assignment of standard errors contrasts with those assigned in Mann et al.'s (1999) annually-resolved series, where the uncertainties were assigned only for pre-instrumental data points in their original publication (that assumption of 'error-free' instrumental thermometer data is incorrect-see Jones et al. 1999, Folland et al. 2001). Over the full 2nd millennium, Esper et al. (2002) deduced a slightly larger range in their confidence limits after 1950 (compared to the pre-1950 interval extending back to 800) and attributed those higher uncertainties to the accounting for the anomalous modern ring-growth problem (Graybill \& Idso 1993, Jacoby \& D'Arrigo 1995, Briffa et al. 1998, Feng 1999, Barber et al. 2000, Jacoby et al. 2000, Knapp et al. 2001).

\section{CONCLUSION}

Many interesting questions on the geographical nature and physical factors of surface temperature or precipitation changes over the last $1000 \mathrm{yr}$ cannot be quantitatively and conclusively answered by current knowledge. The adopted period of $1000 \mathrm{yr}$ is strictly a convenience that merits little scientific weight.

Climate proxy research provides an aggregate, broad perspective on questions regarding the reality of Little Ice Age, Medieval Warm Period and the 20th century surface thermometer global warming. The picture emerges from many localities that both the Little Ice Age and Medieval Warm epoch are widespread and near-synchronous phenomena, as conceived by Bryson et al. (1963), Lamb (1965) and numerous researchers since. Overall, the 20th century does not contain the warmest anomaly of the past millennium in most of the proxy records, which have been sampled world-wide. Past researchers implied that unusual 20th century warming means a global human impact. However, the proxies show that the 20th century is not unusually warm or extreme.

The lack of unusual warmth in the 20th century does not argue against human impacts on local and regional scales (perhaps on scales as small as 10 to $1000 \mathrm{~km}^{2}$ for precipitation and $10^{4}$ to $10^{5} \mathrm{~km}^{2}$ for temperature). Recently, Lawton et al. (2001) demonstrated how the deforested areas of tropical lowlands can, in combination with favorable topographical conditions and altered atmospheric air flow across the landscape, significantly raise the bases of convective and orographic clouds around the Monteverde montane cloud forests of Costa Rica during the dry season, and thus drastically impact local ecosystems. It is thus clear that human activity affects local environment and climate. On the other hand, A. T. Grove (2001) advised caution when interpreting dubious claims about the dominant role played by human activity such as in deforestation, agricultural expansion and population growth on geomorphological changes in Mediterranean Europe. In particular, A. T. Grove (2001) showed that the wide spread occurrence of the medieval fluvial terrace 
called the 'younger fill' around Mediterranean Europe was more powerfully influenced by increased frequency of deluges during Alpine glacier advances associated with the Little Ice Age than by soil erosion and rapid sedimentation caused by deforestation.

Acknowledgements. This work was supported by funds from the American Petroleum Institute (01-0000-4579), the Air Force Office of Scientific Research (Grant AF49620-02-10194) and the National Aeronautics and Space Administration (Grant NAG5-7635). The views expressed herein are those of the authors and are independent of the sponsoring agencies. We have benefitted greatly from the true and kind spirit of research communications (including a preview of their thoughts) with the late Jean Grove (who passed away on January 18, 2001), Dave Evans, Shaopeng Huang, Jim Kennett, Yoshio Tagami and Referee \#3. We thank John Daly, Diane Douglas-Dalziel, Craig and Keith Idso for their unselfish contributions to the references. We also thank the Editor, Chris de Freitas, for very helpful editorial changes that improved the manuscript. We are very grateful to Maria McEachern, Melissa Hilbert, Barbara Palmer and Will Graves for invaluable library help, and both Philip Gonzalez and Lisa Linarte for crucial all-around help.

\section{LITERATURE CITED}

Andrén E, Andrén T, Sohlenius G (2000) The Holocene history of the southwestern Baltic Sea as reflected in sediment core from the Bornholm Basin. Boreas 29:233-250

Aristarain AJ, Jouzel J, Lorius C (1990) A 400 years isotope record of the Antarctic Peninsula climate. Geophys Res Lett 17:2369-2372

Arseneault D, Payette S (1997) Reconstruction of millennial forest dynamics from tree remains in a subarctic tree line peatland. Ecology 78:1873-1883

Aykroyd RG, Lucy D, Pollard AM, Carter AHC, Robertson I (2001) Temporal variability in the strength of the proxyclimate correlations. Geophys Res Lett 28:1559-1562

Barber VA, Juday GP, Finney BP (2000) Reduced growth of Alaskan white spruce in the twentieth century from temperature-induced drought stress. Nature 405:668-673

Barclay DJ, Wiles GC, Calkin PE (1999) A 1119-year treering-width chronology from western Prince William Sound, southern Alaska. Holocene 9:79-84

Barlow LK, Sadler JP, Ogilvie AEJ, Buckland PC and 5 others (1997) Interdisciplinary investigations of the end of the Norse Western Settlement in Greenland. Holocene 7:489-499

Barnett T, Hasselmann K, Chelliah M, Delworth T and 7 others (1999) Detection and attribution of recent climate change: a status report. Bull Am Meteor Soc 80:2631-2659

Baroni C, Orombelli G (1994) Holocene glacier variations in the Terra Nova Bay area (Victoria Land, Antarctica). Antarctic Sci 6:497-505

Beltrami H, Taylor AE (1995) Records of climatic change in the Canadian Arctic: towards calibrating oxygen isotope data with geothermal data. Glob Planet Change 11: $127-138$

Beltrami H, Chapman DS, Archambault S, Bergeron Y (1995) Reconstruction of high resolution ground temperature histories combining dendrochronological and geothermal data. Earth Planet Sci Lett 136:437-445

Beltrami H, Wang J, Bras RL (2000) Energy balance at the
Earth's surface: heat flux history in eastern Canada. Geophys Res Lett 27:3385-3388

Benoist JP, Jouzel J, Lorius C, Merlivat L, Pourchet M (1982) Isotope climatic record over the last $2.5 \mathrm{ka}$ from Dome $\mathrm{C}_{\text {, }}$ Antarctica, ice cores. Ann Glaciology 3:17-22

Bernabo JC (1981) Quantitative estimates of temperature changes over the last 2700 years in Michigan based on pollen data. Quat Res 15:143-159

Bianchi GG, McCave IN (1999) Holocene periodicity in North Atlantic climate and deep-ocean flow south of Iceland. Nature 397: 515-517

Biondi F, Perkins DL, Cayan DR, Hughes MK (1999) July temperature during the second millennium reconstructed from Idaho tree rings. Geophys Res Lett 26: 1445-1448

Black DE, Peterson LC, Overpeck JT, Kaplan A, Evans MN, Kashgarian M (1999) Eight centuries of North Atlantic Ocean atmosphere variability. Science 286: 1709-1713

Blackford JJ, Chambers FM (1995) Proxy climate record for the last 1000 years from Irish blanket peat and a possible link to solar variability. Earth Planet Sci Lett 133:145-150

Bodri L, Cermák (1999) Climate change of the last millennium inferred from borehole temperatures: regional patterns of climatic changes in the Czech Republic. Part III. Glob Planet Change 21:225-235

Bond G, Showers W, Cheseby M, Lotti R and 6 others (1997) A pervasive millennial-scale cycle in North Atlantic holocene and glacial climates. Science 278:1257-1266

Bond G, Showers W, Elliot M, Evans M, Lotti R, Hajdas I, Bonani G, Johnson S (1999) The North Atlantic's 1-2 kyr climate rhythm: relation to Heinrich events, Dansgaard/ Oeschger cycles and the little ice age. In Clark PU, Webb RS, Keigwin LD (eds) Mechanisms of global climate change at millennial time scales, Vol 112. American Geophysical Union Press, Washington DC, p 35-58

Borisenkov YeP (1995) Documentary evidence from the U.S.S.R. In: Bradley RS, Jones PD (eds) Climate since A.D. 1500. Routledge, New York, p 171-183

Bradley RS, Jones PD (1993) 'Little Ice Age' summer temperature variations: their nature and relevance to recent global warming trends. Holocene 3:367-376

Bradley RS, Briffa KR, Crowley TJ, Hughes MK, Jones PD, Mann ME (2001) The scope of Medieval Warming. Science 292:2011-2012

Briffa KR (2000) Annual climate variability in the Holocene: interpreting the message of ancient trees. Quat Sci Rev 19: 87-105

Briffa KR, Jones PD, Bartholin TS, Eckstein D, Schweingruber FH, Karlen W, Zetterberg P, Eronen M (1992) Fennoscandian summers from AD 500: temperature changes on short and long timescales. Clim Dyn 7:111-119

Briffa KR, Schweingruber FH, Jones PD, Osborn TJ, Harris IC, Shiyatov SG, Vaganov EA, Grudd H (1998) Trees tell of past climates: but are they speaking less clearly today? Phil Trans R Soc Lond B 353:65-73

Briffa KR, Osborn TJ, Schweingruber FH, Harris IC, Jones PD, Shiyatov SG, Vaganov EA (2001) Low-frequency temperature variations from a northern tree-ring density network. J Geophys Res 106:2929-2941

Broecker WS (2001) Was the medieval warm period global? Science 291:1497-1499

Bryson RA (1985) On climatic analogs in paleoclimatic reconstruction. Quat Res 23:275-286

Bryson RA, Bryson RU (1997) High resolution simulations of regional holocene climate: North Africa and the Near East. In: Dalfes HN, Kukla G, Weiss H (eds) Third millenium BC climate change and the Old World collapse. NATO ASI Series, Vol. 149. Springer-Verlag, Heidelberg, p 565-593 
Bryson RA, Arakawa H, Aschmann HH, Baerris DA and 36 others (1963) NCAR Technical Note. In: Bryson RA, Julian PR (eds) Proc Conf Climate of the 11th and 16th Centuries, Aspen CO, June 16-24 1962, National Center for Atmospheric Research Technical Notes 63-1, Boulder CO

Bryson RA, Irving WN, Larsen JA (1965) Radiocarbon and soil evidence of former forest in the Southern Canadian Tundra. Science 147:46-48

Calkin PE, Wiles GC, Barclay DJ (2001) Holocene coastal glaciation of Alaska. Quat Sci Rev 20:449-461

Carignano CA (1999) Late Pleistocene to recent climatic chance in Córdoba Province, Argentina: geomorphological evidence. Quat Int 57-58:117-134

Chan JCL, Shi JE (2000) Frequency of typhoon landfall over Guangdong province of China during the period 1470-1931. Int J Clim 20:183-190

Cioccale MA (1999) Climatic fluctuations in the central region of Argentina in the last 1000 years. Quat Int 62:35-47

Clapperton CM, Sugden DE, Birnie J, Wilson MJ (1989) Lateglacial and holocene glacier fluctuations and environmental change on South Georgia, Southern Ocean. Quat Res 31:210-228

Clow GD (1992) The extent of temporal smearing in surfacetemperature histories derived from borehole temperature measurements. Palaeogeogr Palaeoclim Palaeoecol 98: 81-86

Clow GD, Waddington ED (1999) Quantification of natural climate variability in Central Greenland and East Antarctica using borehole paleothermometry (abstract). International Union of Geodesy and Geophysics XXII General Assembly Abstract Book: B249, Birmingham UK

Cohen AL, Tyson PD (1995) Sea-surface temperature fluctuations during the Holocene off the south coast of Africa: implications for terrestrial climate and rainfall. Holocene 5: 304-312

Collins M, Osborn TJ, Tett SFB, Briffa KR, Schweingruber FH (2002) A comparison of the variability of a climate model with paleotemperature estimates from a network of treering indices. J Clim 15:1497-1515

Cook ER, Buckley BM, D'Arrigo RD, Peterson MJ (2000) Warm-season temperatures since 1600 BC reconstructed from Tasmanian tree rings and their relationship to largescale sea surface temperature anomalies. Clim Dyn 16: 79-91

Cowling SA, Skyes MT (1999) Physiological significance of low atmospheric $\mathrm{CO}_{2}$ for plant-climate interactions. Quat Res 52:237-242 (See additional research exchanges in Quat Res 53:402-404 and Quat Res 53:405-406)

Crowley TJ, Lowery TS (2000) How warm was the medieval warm period? Ambio 29:51-54

Dahl-Jensen D, Mosegaard K, Gundestrup N, Glow GD, Johnsen SJ, Hansen AW, Balling N (1998) Past temperatures directly from the Greenland ice sheet. Science 282:268-271

Dansgaard W, Johnsen SJ, Reeh N, Gundestrup N, Clausen HB, Hammer CU (1975) Climatic changes, Norsemen and modern man. Nature 255:24-28

D'Arrigo RD, Cook ER, Salinger J, Palmer J, Buckley BM, Krusic PJ, Villalba R (1998) Tree-ring records from New Zealand: long-term context for recent warming trend. Clim Dyn 14:191-199

D'Arrigo RD, Jacoby G, Frank D, Pederson N and 5 others (2001) 1738 years of Mongolian temperature variability inferred from a tree-ring width chronology of Siberian Pine. Geophys Res Lett 28:543-546

Davis OK (1994) The correlation of summer precipitation in the southwestern USA with isotopic records of solar activ- ity during the Medieval Warm Period. Clim Change 26: 271-287

Dean WE, Schwalb A (2000) Holocene environmental and climatic change in the Northern Great Plains as recorded in the geochemistry of sediments in Pickerel Lake, South Dakota. Quat Int 67:5-20

deMenocal P (2001) Cultural responses to climate change during the late Holocene. Science 292:667-673

deMenocal P, Ortiz J, Guilderson T, Sarnthein M (2000) Coherent high- and low-latitude climate variability during the Holocene warm period. Science 288:2198-2202

Domack EW, Mayewski PA (1999) Bi-polar ocean linkages: evidence from late-holocene Antarctic marine and Greenland ice-core records. Holocene 9:247-251

Domack E, Leventer A, Dunbar R, Taylor F, Brackfeld S, Sjunneskog C plus ODP Leg 178 Team (2001) Chronology of the Palmer Deep site, Antarctic Peninsula: a holocene palaeoenvironmental reference for the circum-Antarctic. Holocene 11:1-9

Doran PT, Priscu JC, Lyons WB, Walsh JE and 9 others (2002) Antarctic climate cooling and terrestrial ecosystem response. Nature 415:517-520 (see also exchanges between Turner et al. and Walsh, Doran et al. (2002) in Recent temperature trends in the Antarctic. Nature 418:291-292)

Druffel EM (1982) Banded corals: Changes in Oceanic carbon-14 during the Little Ice Age. Science 218:13-19

Dyurgerov MB, Meier MF (2000) Twentieth century climate change: evidence from small glaciers. Proc Natl Acad Sci USA 97:1406-1411

Ely LL, Enzel Y, Baker VR, Cayan DR (1993) A 5000-year record of extreme floods and climate change in the southwestern United States. Science 262:410-412

Esper J, Cook ER, Schweingruber FH (2002) Low-frequency signals in long tree-ring chronologies for reconstructing past temperature variability. Science 295:2250-2253

Evans DJA (2000) Ice in a greenhouse: the impacts of global warming on world glacier cover. Trans Inst Engineers and Shipbuilders in Scotland 143:11-19

Evans MN, Kaplan A, Cane MA, Villalba R (2000) Globality and optimality in climate field reconstructions from proxy data. In: Markgraf V (ed) Inter-hemispheric climate linkages. Academic Press, San Diego, CA p 53-72

Evans MN, Kaplan A, Cane MA (2002) Pacific sea surface temperature field reconstruction from coral $\delta^{18} \mathrm{O}$ data using reduced space objective analysis. Paleocean 17:10.1029/ 2000PA000590

Feng X (1999) Trends in intrinsic water-use efficiency of natural trees for the past 100-200 years. Geochimica et Cosmochim Acta 63:1891-1903

Feng X, Epstein S (1994) Climatic implications of an 8000year hydrogen isotope time series from Bristlecone Pine trees. Science 265:1079-1081

Filippi ML, Lambert P, Hunziker J, Kübler B, Bernasconi S (1999) Climatic and anthropogenic influence on the stable isotope record from bulk carbonates and ostracodes in Lake Neuchâtel, Switzerland, during the last two millenia. J Paleolim 21:19-34

Folland CK, Rayner NA, Brown SJ, Smith TM and 7 others (2001) Global temperature change and its uncertainties since 1861. Geophys Res Lett 28:2621-2624

Graumlich LJ (1993) A 1000-year record of temperature and precipitation in the Sierra Nevada. Quat Res 39:249-255

Graybill DA, Idso SB (1993) Detecting the aerial fertilization effect of atmospheric $\mathrm{CO}_{2}$ enrichment in tree-ring chronologies. Glob BioGeoChem Cyc 7:81-95

Grissino-Mayer HD (1996) A 2129-year reconstruction of pre- 
cipitation for northwestern New Mexico, USA. In Dean JS, Meko DM, Swetnam TW (eds) Tree rings, environment and humanity, Radiocarbon (U Arizona Press), Tucson, p 191-204

Grove AT (2001) The 'Little Ice Age' and its geomorphological consequences in Mediterranean Europe. Clim Change 48: 121-136

Grove JM (1996) The century time-scale. In: Driver TS, Chapman GP (eds) Time-scales and environmental change. Routledge, London p 39-87

Grove JM (2001a) The initiation of the Little Ice Age in regions round the North Atlantic. Clim Change 48:53-82

Grove JM (2001b) The onset of the Little Ice Age. In: Jones PD, Ogilvie AEJ, Davies TD, Briffa KR (eds) History and climate-memories of the future? Kluwer Academic Publishers, New York p 153-185

Grove JM, Conterio A (1995) The climate of Crete in the sixteenth and seventeenth centuries. Clim Change 30: 223-247

Grove JM, Switsur R (1994) Glacial geological evidence for the medieval warm period. Clim Change 26:143-169

Hadly EA (1996) Influence of late-Holocene climate on Northern Rocky Mountain mammals. Quat Res 46:289-310

Häkkinen S (2000) Decadal air-sea interaction in the North Atlantic based on observations and modeling results. J Clim 13:1195-1219

Hansen J, Ruedy R, Glascoe J, Sato M (1999) GISS analysis of surface temperature change. J Geophys Res 104: 30997-31022

Harris RN, Chapman DS (2001) Mid-latitude ( $30^{\circ}$ to $\left.60^{\circ} \mathrm{N}\right)$ climatic warming inferred by combining borehole temperatures with surface air temperatures. Geophys Res Lett 28:747-750

Haug GH, Hughen KA, Sigman DM, Peterson LC, Röhk U (2001) Southward migration of the intertropical convergence zone through the holocene. Science 293:1304-1308

Hendy EJ, Gagan MK, Alibert CA, McCulloch MT, Lough JM, Isdale PJ (2002) Abrupt decrease in tropical Pacific sea surface salinity at end of Little Ice Age. Science 295:1511-1514

Hiller A, Boettger T, Kremenetski C (2001) Mediaeval climatic warming recorded by radiocarbon date alpine treeline shift on the Kola Peninsula, Russia. Holocene 11: 491-497

Hodell DA, Brenner M, Curtis JH, Guilderson T (2001) Solar forcing of drought frequency in the Maya lowlands. Science 292:1367-1370

Holzhauser H (1997) Fluctuations of the Grosser Aletsch Glacier and the Groner Glacier during the last 3200 years: New results. In Frenzel B, Boulton GS, Glser B, Huckriede U (eds) Glacier fluctuations during the Holocene, Akademie der Wissenschaften und der Literatur, p 35-58

Hong YT, Jiang HB, Liu TS, Zhou LP and 5 others (2000) Response of climate to solar forcing recorded in a 6000year $\delta^{18} \mathrm{O}$ time-series of Chinese peat cellulose. Holocene 10:1-7

Hu FS, Ito E, Brown TA, Curry BB, Engstrom DR (2001) Pronounced climatic variations in Alaska during the last two millenia. Proc Natl Acad Sci USA 98:10552-10556

Huang S, Shen PY, Pollack HN (1996) Deriving century-long trends of surface temperature change from borehole temperatures. Geophys Res Lett 23:257-260

Huang S, Pollack HN, Shen PY (1997) Late Quaternary temperature changes seen in the world-wide continental heat flow measurements. Geophys Res Lett 24:1947-1950

Huang S, Pollack HN, Shen PY (2000) Temperature trends over the past five centuries reconstructed from borehole temperatures. Nature 403:756-758

Huffman TN (1996) Archaeological evidence for climatic change during the last 2000 years in Southern Africa. Quat Int 33:55-60

Hughes MK, Diaz HF (1994) Was there a 'Medieval Warm Period', if so, where and when? Clim Change 26:109-142

Idso SB (1989) Letter to the editor-a problem for paleoclimatology? Quat Res 31:433-434

Ingram MJ, Underhill DJ, Wigley TML (1978) Historical climatology. Nature 276:329-334

Iriondo M (1999) Climatic changes in the South American plains: records of a continent-scale oscillation. Quat Int 57-58:93-112

Jacoby GC, D'Arrigo RD (1995) Tree-ring width and density evidence for climatic and potential forest change in Alaska. Glob Biogeochem Cyc 9:227-234

Jacoby GC, D'Arrigo RD, Davaajamts T (1996) Mongolian tree rings and 20th-century warming. Science 273: 771-773

Jacoby GC, Lovelius NV, Shumilov OI, Raspopov OM, Karbainov JM, Frank DC (2000) Long-term temperature trends and tree growth in the Taymir region of northern Siberia. Quat Res 53:312-318

Jennings AE, Weiner NJ (1996) Environmental change in eastern Greenland during the last 1300 years: evidence from foraminifera and lithofacies in Nansen Fjord, $68^{\circ} \mathrm{N}$. Holocene 6:171-191

Jenny B, Valero-Garces B, Urrutia R, Kelts K, Veit H, Appleby PG, Geyh M (2002) Moisture changes and fluctuations of the Westerlies in Mediterranean Central Chile during the last 2000 years: the Laguna Aculeo record $\left(33^{\circ}-50^{\circ} \mathrm{S}\right)$. Quat Int 87:3-18

Johnson TC, Barry S, Chan Y, Wilkinson P (2001) Decadal record of climate variability spanning the past $700 \mathrm{yr}$ in the Southern tropics of East Africa. Geology 29:83-86

Jones PD, Briffa KR, Barnett TP, Tett SFB (1998) Highresolution palaeoclimatic records for the last millennium: interpretation, integration and comparison with General Circulation Model control-run temperatures. Holocene 8: $455-471$

Jones PD, New M, Parker DE, Martin S, Rigor IG (1999) Surface air temperatures and its changes over the past 150 years. Rev Geophys 37:173-199

Jones PD, Osborn TJ, Briffa KR (2001) The evolution of climate over the last millennium. Science 292:662-667

Karlén W (1998) Climate variations and the enhanced greenhouse effect. Ambio 27: 270-274

Karlöf L, Winther JG, Isaksson E, Kohler JF and 10 others (2000) A 1500 year record of accumulation at Amundsenisen western Dronning Maud Land, Antarctica, derived from electrical and radioactive measurements on a 120 m ice core. J Geophys Res 105: 12471-12483

Kaser G (1999) A review of the modern fluctuations of tropical glaciers. Glob Planet Change 22:93-103

Keigwin LD (1996) The little ice age and medieval warm period in the Sargasso Sea. Science 274:1504-1508

Kitagawa H, Matsumoto E (1995) Climatic implications of $\delta^{13} \mathrm{C}$ variations in a Japanese cedar Cryptomeria japonica during the last two millenia. Geophys Res Lett 22:2155-2158

Knapp PA, Soulé PT, Grissino-Mayer HD (2001) Post-drought growth responses of western juniper (Juniperus occidentalis var. occidentalis) in central Oregon. Geophys Res Lett 28:2657-2660

Knappenberger PC, Michaels PJ, Davis RE (2001) Nature of observed temperature changes across the United States during the 20th century. Clim Res 17:45-53 
Koerner RM (1977) Devon Island ice cap: core stratigraphy and paleoclimate. Science 196:15-18

Koerner RM, Fisher DA (1990) A record of Holocene summer climate from a Canadian high-Arctic ice core. Nature 343: 630-631

Korhola A, Weckström J, Holmström L, Erästö P (2000) A quantitative Holocene climatic record from diatoms in Northern Fennoscandia. Quat Res 54:284-294

Kreutz KJ, Mayewski PA, Meeker LD, Twickler MS, Whitlow SI, Pittalwala II (1997) Bipolar changes in atmospheric circulation during the Little Ice Age. Science 277: 1294-1296

Kuhnert H, Pätzold J, Schnetger B, Wefer G (2002) Seasurface temperature variability in the 16th century at Bermuda inferred from coral records. Palaeogeogr Palaeoclim Palaeoecol 179:159-171

Laird KR, Fritz SC, Maasch KA, Cumming BF (1996) Greater drought intensity and frequency before AD 1200 in the Northern Great Plains, USA. Nature 384:552-554

Lamb HH (1965) The early medieval warm epoch and its sequel. Palaeogeogr Palaeoclim Palaeoecol 1:13-37

Lamb HH (1977) Climate-Past, Present and Future Vol. 2 Climatic History and Future, Methuen

Lamb HH (1982) Climate history and the modern world, Methuen

Lamoureux SF, Bradley RS (1996) A late Holocene varved sediment record of environmental change from northern Ellesmere Island, Canada. J Paleolim 16:239-255

Lara A, Villalba R (1993) A 3260-year temperature record from Fitzroya cupressoides tree rings in southern South America. Science 260:1104-1106

Lawton RO, Nair US, Pielke RA Sr, Welch RM (2001) Climatic impact of tropical lowland deforestation on nearby montane cloud forests. Science 294:584-587

Lewis TJ, Wang K (1998) Geothermal evidence for deforestation induced warming: implications for the climatic impact of land development. Geophys Res Lett 25:535-538

Li HC, Bischoff JL, Ku TL, Lund SP, Stot LD (2000) Climate variability in East-Central California during the past 1000 years reflected by high-resolution geochemical and isotopic records from Owens Lake sediments. Quat Res 54: 189-197

Liu K, Yao Z, Thompson LG (1998) A pollen record of Holocene climatic changes from Dunde ice cap, QinghaiTibetan Plateau. Geology 26:135-138

Lotter AF, Birks HJB, Eicher V, Hofmann W, Schwander J, Wick L (2000) Younger Dryas Allerød summer temperatures at Gerzensee (Switzerland) inferred from fossil pollen and cladoceran assemblages. Palaeogeogr Palaeoclim Palaeoecol 159:349-361

Luckman BH (2000) The Little Ice Age in the Canadian Rockies. Geomorph 32:357-384

Luckman BH, Briffa KR, Jones PD, Schweingruber FH (1997) Tree-ring based reconstruction of summer temperatures at Columbia Icefield, Alberta, Canada, AD 1073-1983. Holocene 7:375-389

Luterbacher J, Rickli R, Tinguely C, Xoplaki E and 30 others (2000) Monthly mean pressure reconstruction for the late Maunder Minimum period (AD 1675-1715). Int J Clim 20:1049-1066

Madole RF (1994) Stratigraphic evidence of desertification in the west-central Great Plains within the past $1000 \mathrm{yr}$. Geology 22:483-486

Manley G (1974) Central England temperatures: monthly means 1659 to 1973. Quart J Roy Meteorol Soc 100: 389-405

Mann ME, Bradley RS, Hughes MK (1998) Global-scale tem- perature patterns and climate forcing over the past six centuries. Nature 392:779-787

Mann ME, Bradley RS, Hughes MK (1999) Northern Hemisphere temperatures during the past millennium: inferences, uncertainties, and limitations. Geophys Res Lett 26:759-762

Mann ME, Grille E, Bradley RS, Hughes MK, Overpeck J, Keimig FT, Gross W (2000) Global temperature patterns in past centuries: an interactive presentation. Earth Interact 4:1-29 [available online http://Earthinteraction.org]

Marshall GJ, Lagun V, Lachlan-Cope TA (2002) Changes in Antarctic Peninsula tropospheric temperatures from 1956 to 1999: a synthesis of observations and reanalysis data. Int J Clim 22:291-310

Marshall J, Johnson H, Goodman J (2001) A study of the interaction of the North Atlantic Oscillation with ocean circulation. J Clim 14:1399-1421

McDermott F, Mattey DP, Hawkesworth C (2001) Centennial-scale Holocene climate variability revealed by a highresolution speleothem $\delta^{18} \mathrm{O}$ record from SW Ireland. Science 294:1328-1331

Meese DA, Gow AJ, Grootes P, Mayewski PA and 5 others (1994) The accumulation record from the GISP2 core as an indicator of the climate change throughout the Holocene. Science 266:1680-1682

Mercer JH (1978) West Antarctic ice sheet and $\mathrm{CO}_{2}$ greenhouse effect: a threat of disaster. Nature 271:321-325

Morgan VI (1985) An oxygen isotope climate record from the Law Dome, Antarctica. Clim Change 7:415-426

Mosley-Thompson E (1995) Paleoenvironmental conditions in Antarctica since A.D. 1500: ice core evidence. In: Bradley RS, Jones PD (eds) Climate since A.D. 1500, Routledge, New York, p 572-591

Mosley-Thompson E, Thompson LG (1982) Nine centuries of microparticles deposition at the South Pole. Quat Res $17: 1-13$

Naurzbaev MM, Vaganov EA (2000) Variation of early summer and annual temperature in east Taymir and Putorian (Siberia) over the last two millenia. J Geophys Res 105: 7317-7326

Ogilvie AEJ (1984) The past climate and sea-ice record from Iceland. Part 1. Data to A.D. 1780. Clim Change 6:131-152

Ogilvie A, Farmer G (1997) Documenting the medieval climate. In: Hulme M, Barrow E (eds) Climate of the British Isles-present, past and future. Routledge, London, p 112-133

Ogilvie AEJ, Jónsson T (2001) 'Little Ice Age' research: a perspective from Iceland. Clim Change 48:9-52

Ogilvie AEJ, Barlow LK, Jennings AE (2000) North Atlantic climate c. A.D. 1000: millennial reflections on the Viking discoveries of Iceland, Greenland and North America. Weather 55:34-45

Overpeck J, Hughen K, Hardy D, Bradley R 14 others (1997) Arctic environmental change of the last four centuries. Science 278:1251-1256

Pederson JL (2000) Holocene paleolakes of Lake Canyon, Colorado Plateau: Paleoclimate and landscape response from sedimentology and allostratigraphy. Geol Soc Amer Bull 112:147-158

Perry CA, Hsu KJ (2000) Geophysical, archaeological, and historical evidence support a solar-output model for climate change. Proc Natl Acad Sci USA 97:12433-12438

Petersen KL (1994) A warm and wet little climatic optimum and a cold and dry little ice age in the Southern Rocky Mountains, USA. Clim Change 26:243-269

Pfister C (1995) Monthly temperature and precipitation in central Europe 1525-1979: quantifying documentary evidence 
on weather and its effects. In: Bradley RS, Jones PD (eds) Climate since A.D. 1500. Routledge, New York, p 118-142 Pfister C, Luterbacher J, Schwarz-Zanetti G, Wegmann M (1998) Winter air temperature variations in western Europe during the early and high Middle ages (AD 750-1300). Holocene 8:535-552

Pisias NG (1978) Paleoceanography of the Santa Barbara Basin during the last 8000 years. Quat Res 10:366-384

Porter SC (1981) Glaciological evidence of holocene climatic change. In: Wigley TML, Ingram MJ, Farmer G (eds) Climate and history - studies in past climates and their impact on man. Cambridge University Press, Cambridge, p 82-110

Porter SC (1986) Pattern and forcing of the Northern Hemisphere glacier variations during the last millennium. Quat Res 26:27-48

Proctor CJ, Baker A, Barnes WL, Gilmour MA (2000) A thousand year speleothem proxy record of North Atlantic climate from Scotland. Clim Dyn 16:815-820

Ramesh R (1993) First evidence for Little Ice Age and Medieval Warming in India (abstract). EOS Trans AGU suppl 74: 118

Ren G (1998) Pollen evidence for increased summer rainfall in the Medieval Warm Period at Maili, Northeast China. Geophys Res Lett 25:1931-1934

Robinson WA, Hansen J, Ruedy R (2001) Where's the heat? Insights from GCM experiments into the lack of Eastern U.S. warming. American Meteor Soc 81st Annual Meeting, Albuquerque NM, January 14-19 2001 (abstract) American Meteorological Society, Washington DC

Rodrigo FS, Esteban-Parra MJ, Pozo-Vázquez D, Castro-Díez Y (2000) Rainfall variability in southern Spain on decadal to centennial time scales. Int J Clim 20:721-732

Rott H, Skvarca P, Nagler T (1996) Rapid collapse of northern Larsen ice shelf, Antarctica. Science 271:788-792

Schleser GH, Helle G, Lücke A, Vos H (1999) Isotope signals as climate proxies: the role of transfer functions in the study of terrestrial archives. Quat Sci Rev 18:927-943

Schmutz C, Luterbacher J, Gyalistras D, Xoplaki E, Wanner H (2000) Can we trust proxy-based NAO index reconstructions? Geophys Res Lett 27:1135-1138

Schuster PF, White DE, Naftz DL, Cecil LD (2000) Chronological refinement of an ice core record at Upper Fremont Glacier in south central North America. J Geophys Res 105:7317-7326

Scuderi LA (1993) A 2000-year tree ring record of annual temperatures in the Sierra Nevada mountains. Science 259: 1433-1436

Seager R, Kushnir Y, Visbeck M, Naik N, Miller J, Krahmann G, Cullen H (2000) Causes of Atlantic ocean climate variability between 1958 and 1998. J Clim 13:2845-2862

Serre-Bachet F (1994) Middle ages temperature reconstructions in Europe, a focus on Northeastern Italy. Clim Change 26:213-240

Shi Y, Yao T, Yang B (1999) Decadal climatic variations recorded in Guliya ice core and comparison with the historical documentary data from East China during the last 2000 years. Sci in China Ser D (suppl) 42:91-100

Skinner WR, Majorowicz JA (1999) Regional climatic warming and associated twentieth century land-cover changes in north-western North America. Clim Res 12:39-52

Slonosky VC, Yiou P (2001) The North Atlantic Oscillation and its relationship with near surface temperature. Geophys Res Lett 28:807-810

Smith RC, Ainley D, Baker K, Domack E and 7 others (1999) Marine ecosystem sensitivity to climate change. Bioscience 49:393-404
Song J (2000) Changes in dryness/wetness in China during the last 529 years. Int J Clim 20:1003-1015

Stahle DW, Cleaveland MK, Hehr JG (1988) North Carolina climate changes reconstructed from tree rings: A.D. 372 to 1985. Science 240: 1517-1519

Stine S (1994) Extreme and persistent drought in California and Patagonia during medieval time. Nature 369:546-549

Stine S (1998) Medieval climatic anomaly in the Americas. In: Issar AS, Brown N (eds) Water, environment and society in times of climatic change. Kluwer Academic Press, Dordrecht, p 43-67

Stuiver M, Grootes PM, Braziunas TF (1995) The GISP2 $\delta^{18} \mathrm{O}$ climate record of the past 16,500 years and the role of the Sun, ocean and volcanoes. Quat Res 44:341-354

Swetnam TW (1993) Fire history and climate change in Giant Sequoia groves. Science 262:885-889

Tagami Y (1993) Climate change reconstructed from historical data in Japan. In: Proc Int Symp Global Change by IGBP March 27-29 1992, Tokyo. International GeosphereBiosphere Programme-IGBP, Tokyo, p 720-729

Tagami Y (1996) Some remarks on the climate in the Medieval Warm Period of Japan. In: Mikami $T_{\text {, }}$ Matsumoto E, Ohta S, Sweda T (eds) Paleoclimate and environmental variability in Austral-Asian transect during the past 2000 years (IGBP Proceedings). International Geosphere-Biosphere Programme-IGBP, Nagoya, p 115-119

Tarussov A (1995) The Arctic from Svalbard to Severnaya Zemlya: climatic reconstructions from ice cores. In Bradley RS, Jones PD (eds) Climate Since A.D. 1500, Routledge, New York, p 505-516

Thomas RH, Sanderson TJO, Rose KE (1979) Effect of climatic warming on the West Antarctic ice sheet. Nature 277: $355-358$

Thompson LG (2000) Ice core evidence for climate change in the Tropics: implications for our future. Quat Sci Rev 19: 19-35

Thompson LG, Mosley-Thompson E, Dansgaard W, Grootes PM (1986) The little ice age as recorded in the stratigraphy of the tropical Quelccaya ice cap. Science 234:361-364

Thompson LG, Mosley-Thompson E, Davis ME, Bolzan JF and 6 others (1989) Holocene-Late Pleistocene climatic ice core records from Qinghai-Tibetan plateau. Science 246:474-477

Thompson LG, Peel DA, Mosley-Thompson E, Mulvaney R, Dai J, Lin PN, Davis ME, Raymond CF (1994) Climate since AD 1510 on Dyer Plateau, Antarctic Peninsula: evidence for recent climate change. Ann Glaciol 20: $420-426$

Thompson LG, Mosley-Thompson E, Davis ME, Lin PN, Dai J, Bolzan JF, Yao T (1995) A 1000 year climate ice-core record from the Guliya ice cap, China: its relationship to global climate variability. Ann Glaciol 21:175-181

Thompson LG, Yao T, Mosley-Thompson E, Davis ME, Henderson KA, Lin PN (2000) A high-resolution millennial record of the South Asian Monsoon from Himalayan ice cores. Science 289:1916-1919

Till C, Guiot J (1990) Reconstruction of precipitation in Morocco since 1100 A.D. based on Cedrus atlantica treering widths. Quat Res 33:337-351

Tong G, Zhang J, Fan S, Zhao J, Wang G, Wang Y, Wang L, Cui J (1996) Environmental changes at the top of Taibai Mountain, Qinling since 1ka ago. Mar Geol Quat Geol 16: 95-104

Tyson PD, Lindesay JA (1992) The climate of the last 2000 years in southern Africa. Holocene 2:271-278

Tyson PD, Karlén W, Holmgren K, Heiss GA (2000) The Little 
Ice Age and medieval warming in South Africa. South African J Sci 96:121-126

Valero-Garcés BL, Delgado-Huertas A, Ratto N, Navas A, Edwards L (2000) Paleohydrology of Andean saline lakes from sedimentological and isotopic records, Northwestern Argentina. J Paleolimnology 24:343-359

van Engelen AFV, Buisman J, Ijnsen F (2001) A millennium of weather, winds and water in the low countries. In: Jones PD, Ogilvie AEJ, Davies TD, Briffa KR (eds) History and climate-memories of the future? Kluwer Academic Publishers, New York, p 101-124

Vaughan DG, Doake CSM (1996) Recent atmospheric warming and retreat of ice shelves on the Antarctic Peninsula. Nature 379:328-331

Verardo S, Cronin T, Willard D, Kerhin R (1998) Climate and environmental changes recorded by Chesapeake Bay Dinoflagellate cysts in the last millennium. Geol Soc Amer Abs 74: 284

Verschuren D, Laird KR, Cumming BF (2000) Rainfall and drought in equatorial east Africa during the past 1,100 years. Nature 403:410-414

Villalba R (1990) Climatic fluctuations in northern Patagonia during the last 1000 years as inferred from tree-ring records. Quat Res 34:346-360

Villalba R (1994) Tree-ring and glacial evidence for the medieval warm epoch and the little ice age in southern

Editorial responsibility: Chris de Freitas,

Auckland, New Zealand
South America. Clim Change 26:183-197

von Storch JS, Müller P, Bauer E (2001) Climate variability in millennium integrations with coupled atmosphere-ocean GCMs: a spectral view. Clim Dyn 17:375-389

Williams PW, Marshall A, Ford DC, Jenkinson AV (1999) Palaeoclimatic interpretation of stable isotope data from holocene speleothems of the Waitomo district, North Island, New Zealand. Holocene 9:649-657

Wilson AT, Hendy CH, Reynolds CP (1979) Short-term climate change and New Zealand temperatures during the last millennium. Nature 279:315-317

Winkler S (2000) The 'Little Ice Age' maximum in the southern Alps, New Zealand: preliminary results at Mueller Glacier. Holocene 10:643-647

Winter A, Ishioroshi H, Watanabe T, Oba T, Christy J (2000) Carribean sea surface temperatures: two-to-three degrees cooler than present during the Little Ice Age. Geophys Res Lett 27:3365-3368

Woodhouse CA, Overpeck JT (1998) 2000 years of drought variability in the central United States. Bull Am Meteor Soc 79:2693-2714

Yu Z, Ito E (1999) Possible solar forcing of century-scale drought frequency in the northern Great Plains. Geology 27:262-266

Zhang D (1994) Evidence for the existence of the medieval warm period in China. Clim Change 26:289-297

Submitted: April 11, 2002; Accepted: August 29, 2002

Proofs received from author(s): January 3, 2003 